\title{
Physicochemical, mineralogy, and thermo-kinetic characterisation of newly discovered Nigerian coals under pyrolysis and combustion conditions
}

\author{
Bemgba B. Nyakuma ${ }^{1}$ (D) Aliyu Jauro ${ }^{2} \cdot$ Segun A. Akinyemi $^{3} \cdot$ Hasan M. Faizal $^{4}$ • \\ Mohammed B. Nasirudeen ${ }^{5} \cdot$ Muhammad Ariff H. M. Fuad $^{4} \cdot$ Olagoke Oladokun $^{1}$
}

Received: 6 June 2020/Revised: 8 September 2020/ Accepted: 27 November 2020/Published online: 3 January 2021

(C) The Author(s) 2021

\begin{abstract}
In this study, the physicochemical, microstructural, mineralogical, thermal, and kinetic properties of three newly discovered coals from Akunza (AKZ), Ome (OME), and Shiga (SHG) in Nigeria were examined for potential energy recovery. Physicochemical analysis revealed high combustible but low levels of polluting elements. The higher heating values ranged from $18.65 \mathrm{MJ} / \mathrm{kg}$ (AKZ) to $26.59 \mathrm{MJ} / \mathrm{kg}$ (SHG). Microstructure and mineralogical analyses revealed particles with a rough texture, surface, and glassy lustre, which could be ascribed to metals, quartz, and kaolinite minerals. The major elements $(\mathrm{C}, \mathrm{O}, \mathrm{Si}$, and $\mathrm{Al})$, along with minor elements $(\mathrm{Ca}, \mathrm{Cu}, \mathrm{Fe}, \mathrm{K}, \mathrm{Mg}, \mathrm{S}$, and $\mathrm{Ti})$ detected are associated with clays, salts, or the porphyrin constituents of coal. Thermal analysis showed mass loss $\left(M_{\mathrm{L}}\right)$ ranges from $30.51 \%$ to $87.57 \%$ and residual mass $\left(R_{\mathrm{M}}\right)$ from $12.44 \%$ to $69.49 \%$ under combustion (oxidative) and pyrolysis (non-oxidative) TGA conditions due to thermal degradation of organic matter and macerals (vitrinite, inertinite and liptinite). Kinetic analysis revealed the coals are highly reactive under the oxidative and non-oxidative conditions based on the Coats-Redfern Model. The activation energy $\left(E_{\mathrm{a}}\right)$ ranged from 23.81 to $89.56 \mathrm{~kJ} / \mathrm{mol}$, whereas the pre-exponential factor $\left(k_{\mathrm{o}}\right)$ was from $6.77 \times 10^{-4} / \mathrm{min}$ to $1.72 \times 10^{3} / \mathrm{min}$ under pyrolysis and combustion conditions. In conclusion, the coals are practical feedstocks for either energy recovery or industrial applications.
\end{abstract}

Keywords Pyrolysis $\cdot$ Combustion $\cdot$ Coals $\cdot$ Physicochemical $\cdot$ Microstructural $\cdot$ Thermal $\cdot$ Nigeria

Bemgba B. Nyakuma

bbnyax1@gmail.com; bnbevan2@live.utm.my

1 School of Chemical and Energy Engineering, Faculty of Engineering, Universiti Teknologi Malaysia, 81310 Skudai, Johor, Malaysia

2 National Centre for Petroleum Research and Development, Abubakar Tafawa Balewa University, P.M.B 0248, Bauchi, Bauchi State, Nigeria

3 Department of Geology, Faculty of Science, Ekiti State University, P.M.B 5363, Ado-Ekiti, Ekiti State, Nigeria

4 School of Mechanical Engineering, Faculty of Engineering, Universiti Teknologi Malaysia, 81310 Skudai, Johor, Malaysia

5 Department of Chemistry, Faculty of Science, Federal University of Lafia, P.M.B 146, Lafia, Nasarawa State, Nigeria

\section{Introduction}

Coal is a biogenic sedimentary rock derived from complex biochemical and metamorphic processes termed coalification in the earth's crust (Gräbner 2014). In the context of energy recovery, coal is a brown-to-black combustible material that contains high carbon content $(60 \mathrm{wt} \%-$ $87 \mathrm{wt} \%$ ) (Reddy 2013) and higher heating values (14-34 MJ/kg) (Speight 2012). Consequently, coal is predominantly utilised for electric power generation due to its high energy content, widespread availability, and low processing costs (Dorf 2017). Over the years, coal has also become an important feedstock for the production of fuels, chemicals, and industrial raw material for numerous applications (Miller 2016).

According to analysts, coal currently accounts for 38\%$41 \%$ of the global electricity generation (Dai and Finkelman 2018). Consequently, coal-fired electricity production 
accounts for a major share of the global energy mix (BP 2018), particularly in industrialised nations such as Germany, Russia, Poland, UK, China and Australia (Wierzbowski et al. 2017). Over the years, the growing demand for a cheap and reliable supply of electricity has also stimulated significant investments in coal-fired power (Tang et al. 2018) particularly in developing countries such as India, China, and South Africa (Hancox 2016). The highlighted studies submit that coal consumption plays a strategic role in various sectors largely due to the nexus of energy demand and economic growth (Zhao and Alexandroff 2019). Recently, Vietnam, Cambodia, and Mozambique have also begun to invest heavily in coal-fired electricity generation due to the growing energy demands required to catalyse socio-economic growth and infrastructural development (Baruya 2017). Over the years, such investments have ensured a steady supply of low-cost and consistent energy (IEA 2018), which have stimulated fiscal growth, infrastructural development, and poverty alleviation (IEA-CCC 2020).

In the same vein, the discovery of new coal deposits in Nigeria presents numerous opportunities not only for the power and energy sectors (Ohimain 2014) but for socioeconomic growth, infrastructural and industrial development (Oyedepo 2012a). Despite Nigeria's lofty position as the most populous nation and largest economy in Africa, the country is hampered by perennial power cuts, blackouts, and load shedding (Odior and Omadudu 2013). The outlined challenges are ascribed to inadequate electric power generation (Odior and Oyawale 2012) and overreliance on seasonal hydroelectric dams and gas-fired turbines (Musa 2010). Other prominent challenges include distribution losses due to old or low-efficiency transmission infrastructure, and the rising spate of power-cable vandalism (Oseni 2011). Hence, the problem of inadequate power generation needs to be urgently addressed by diversification of the nation's energy mix (Oyedepo 2012b), which currently includes hydropower, natural gas, and biomass (Oyedepo 2014).

One promising approach to address the problem of power generation is the adoption and implementation of coal-fired electricity in the country. At the current estimates, Nigeria's coal reserves amount to approximately 640 million proven tonnes and 2.75 billion tonnes of contingent reserves (Chukwu et al. 2016). However, coal-fired electric power generation is virtually non-existent in the energy mix of Nigeria (Sambo 2009). To this end, there is an urgent need to explore the option of generating electricity from the nation's vast coal reserves (Ocheri 2017), through the design and development of power plants across the various geopolitical regions of the country. The first step in the quest for coal-fired electricity will require comprehensive characterisation of the fuel properties and energy recovery potentials of the coal resources in Nigeria.

Previous studies have examined the source rock potentials (Akande et al. 2007), mineralogy (Ogala et al. 2012), petrology (Wuyep and Obaje 2012), sedimentology (Sonibare et al. 2013), lithostratigraphy (Uzoegbu et al. 2013), hydrocarbon potentials (Jauro et al. 2014), geology (Ayinla et al. 2017b), petrography (Ayinla et al. 2017a), and geochemistry (Akinyemi et al. 2020a) of selected Nigerian coals in the literature. Other studies have examined the physicochemical (Akinyemi et al. 2020a), thermal conversion (Nyakuma et al. 2016), major/trace elements (Sonibare et al. 2013), and kinetic properties (Sonibare et al. 2005) of selected coals from Nigeria. However, there are limited studies that comprehensively examine the fuel, material, and energetic characteristics of Nigerian coals particularly from the Benue trough where there have been numerous discoveries of large deposits in recent times.

In this study, three newly discovered coal samples from Akunza, Ome, and Shiga in Nasarawa State (Nigeria) are comprehensively examined based on the following objectives;

(1) To characterise the physicochemical, microstructural, and mineralogical fuel and materials properties of the new coal samples.

(2) To categorise the new coal samples into various ranks (lignite, sub-bituminous, and bituminous) based on calorific values for potential applications.

(3) To examine the thermal, kinetic and energetic properties of the new coals as potential feedstocks for energy recovery through oxidative/non-oxidative thermal conversion.

It is envisaged that the findings of this study will avail engineers and policymakers with the comprehensive data required to effectively develop and strategically implement plans for future power plants and or the industrial applications of coal resources in Nigeria.

\section{Geological settings}

The Benue Trough is an Inland basin that originated from the early Cretaceous age, forming as a split from the Central West African basement during the separation of African and South American continents known as the breakup of Gondwanaland (Olade 1975). This break up was followed by the separation of these continents, opening up of the South Atlantic, and growth of the Mid Atlantic Ridge (Benkhelil 1989). It forms a regional structure $150 \mathrm{~km}$ wide, which is exposed from the northern frame of the Niger Delta running North-East for about $1000 \mathrm{~km}$ and terminating underneath Lake Chad. The trough contains 
$6 \mathrm{~km}$ thick Cretaceous-Tertiary sediments, including sections pre-dating the middle Santonian, which have been compressed, deformed, folded, faulted, and uplifted in several places, producing more than 100 anticlines and synclines (Benkhelil 1989). Recent evidence from petrographic studies and significant element abundance suggest a passive margin tectonic environment for the Benue Trough (Ogungbesan and Akaegbobi 2011). The Benue Trough is subdivided into the Lower, Middle and Upper parts, as depicted in the geological map of Nigeria in Fig. 1.

The geology and stratigraphic successions in the Benue Trough have been extensively reviewed by various researchers in the literature (Yandoka et al. 2016; Ayinla et al. 2017b). The upper part of the trough bifurcates at its north-eastern end into the Gongola and the Yola basins (Fig. 1). In both basins, the Albian Bima Sandstone lays unconformably on the basement, as illustrated in Fig. 2, and is conformably overlain by the Cenomanian transitional/coastal Yolde Formation, which represents the beginning of marine incursion into the upper Benue Trough. In the middle Benue Trough, around Lafia-Obi, six upper Cretaceous lithogenic formations make up the stratigraphic successions (Fig. 2). The succession is made up of the Albian Arufu, Uomba, and Gboko Formations generally termed the Asu River Group (Offodile 1976). These formations are overlain by the Cenomanian Keana,
Awe, and the Cenomanian-Turonian Ezeaku Formations. The late Turonian early Santonian coal-bearing Awgu Formation lies conformably on the Ezeaku Formation. The post-folding Campanian-Maastrichtian Lafia Formation ended the sedimentation in the middle Benue Trough, after which widespread volcanic activity took over in the Tertiary. The late Turonian/early Santonian coal-bearing Awgu Formation are exposed at Lafia-Obi.

In the lower Benue Trough lies the oldest geological formation overlying the basement is the Asu river group, which is Albian in age. It is marine-based and consists of dark shales, siltstones and fine-grained sandstones passing upwards into shales and limestones (Offodile 1980). This is overlain by the Cross river group, which consists of Odukpani, Agala, Nkalagu and Agbani formations. The only known marine Cenomanian in the coastal basin is found in the Odukpani formation, and it consists of a series of limestone and calcareous sandstones. The Cross River group deposition is followed by the major Santonian folding and erosion episodes. The coal-bearing Mamu Formation is exposed at Okoba, Enugu, Imiegba, Ezimo, Ogboyoga, Owukpa, Udi, on the Enugu-Onitsha Expressway and Agwu-Enugu Escarpment (Ogala 2018).

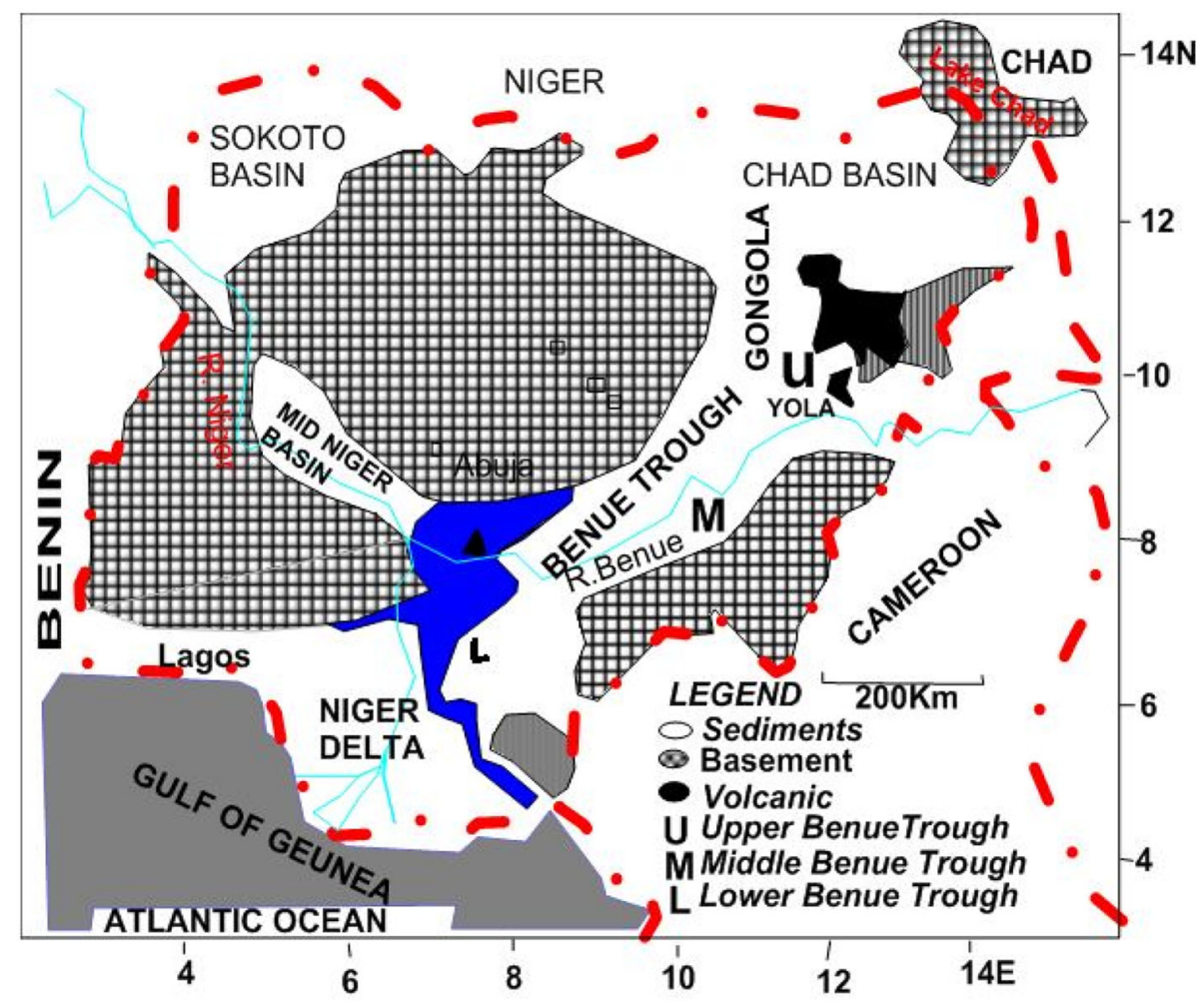

Fig. 1 Geological map of Nigeria showing Benue Trough (Jauro et al. 2007) 


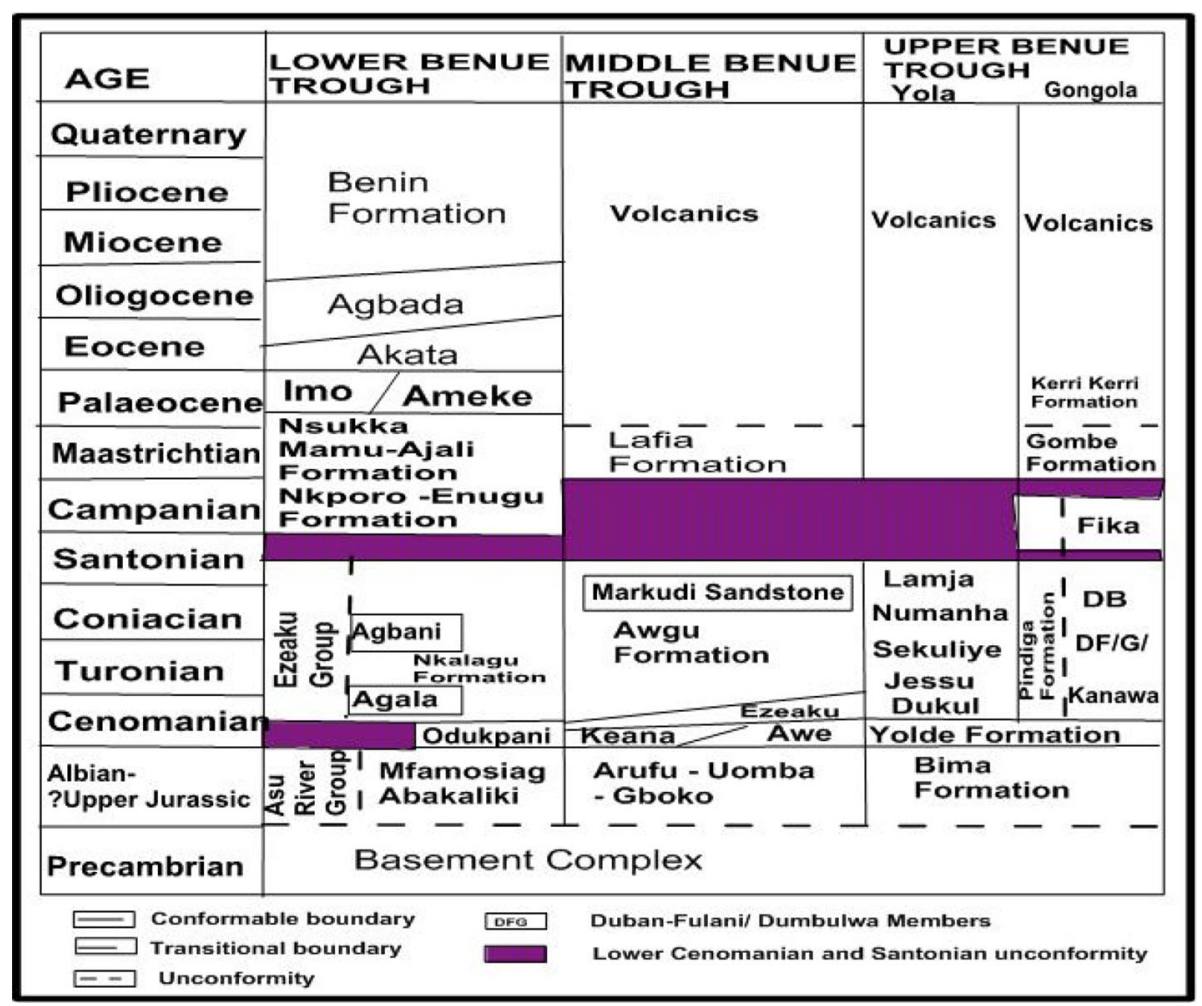

Fig. 2 Stratigraphic succession of the Benue Trough (Abubakar 2014)

\section{Experimental and modelling theory}

\subsection{Coal procurement and preparation}

The coal samples were obtained from the middle Benue Trough, as described in the detailed section on geological settings. Samples were collected from coal mines in Akunza, Ome, and Shiga in Obi Local Government Area of Nasarawa State in Nigeria. The coal samples were bagged, tagged, and labelled AKZ, OME, and SHG for Akunza, Ome, and Shiga, respectively, for ease of identification. Large chunks of the samples were broken down using a handheld hammer and then pulverised in a dry miller (Panasonic Mixer Grinder MX400C, Malaysia). Subsequently, the pulverised coal samples were sifted using an analytical sieve (W.S. Tyler, USA) to obtain homogeneous sized particles below $250 \mu \mathrm{m}$ prior to physicochemical, microstructure, mineralogical, and thermal analyses.

\subsection{Experimental methods}

\subsubsection{Physicochemical fuel properties}

The physicochemical fuel properties of the AKZ, OME, and SHG coal samples were determined by ultimate, proximate, and calorific analyses. Ultimate analysis was performed using the elemental analyser (vario MACRO
Cube, Germany) based on the ASTM standard D5373 for determination of carbon $(\mathrm{C})$, hydrogen $(\mathrm{H})$, nitrogen $(\mathrm{N})$, sulphur $(\mathrm{S})$. However, the oxygen $(\mathrm{O})$ content was determined by difference from the sum of CHNS. Proximate analysis was carried out by thermogravimetric analysis (TGA) to determine the composition of moisture (M), volatile matter (VM), ash (A), and fixed carbon (FC) based on the procedure described in the literature (Donahue and Rais 2009). For the proximate test, $15 \pm 0.50 \mathrm{mg}$ of each coal sample was placed in an alumina crucible and heated at $50{ }^{\circ} \mathrm{C} / \mathrm{min}$ from room temperature (RT) to $110^{\circ} \mathrm{C}$, followed by isothermal heating at the final temperature for a hold time of 6 min under nitrogen $\left(\mathrm{N}_{2}\right.$ flow rate of $100 \mathrm{~mL} /$ min) atmosphere. The mass loss (wt\%) of each sample between the RT and $110{ }^{\circ} \mathrm{C}$ was computed as the moisture content. Next, the sample was heated from 110 to $900{ }^{\circ} \mathrm{C}$ and followed by isothermal heating at the final temperature for a hold time of 5 min under nitrogen $\left(\mathrm{N}_{2}\right.$ flow rate of $100 \mathrm{~mL} / \mathrm{min}$ ) atmosphere. The loss of mass (wt \%) of each sample between the 110 and $900{ }^{\circ} \mathrm{C}$ was computed as the volatile matter (VM) content. On completion, the gas flow was switched to air (flow rate of $100 \mathrm{~mL} / \mathrm{min}$ ) flow to ensure combustion of the fixed carbon at $900{ }^{\circ} \mathrm{C}$. The final or residual of mass was computed to determine the ash (A) content of each sample examined in this study. The higher heating values were measured by bomb calorimetry 
(IKA C2000, USA) based on the procedures of the ASTM standard D-2015.

\subsubsection{Microstructural analyses}

The microstructure of the coals was examined by scanning electron microscopy (SEM). For the tests, each powdered coal sample was spray-coated on the carbon epoxy tapes placed on the SEM sample grain mounts. Next, the samples were sputter-coated with a thin layer of gold (Quorum Q150R S, UK) to eliminate errors due to the charging effect, electron beam damage, as well as to enhance the clarity of the SEM micrographs. The charged samples were then transferred to the sample chamber of the SEM (JEOL JSM IT-300, Germany) for analysis at the operating conditions of $20 \mathrm{kV}$ operating voltage and $5 \mathrm{~mm}$ working distance. The samples were then scanned by mapping to examine the surface microstructure at a magnification of $\times 1000$.

\subsubsection{Mineralogical analyses}

The mineralogical properties of the coal samples were examined by energy-dispersive X-ray (EDX) spectroscopy. The objective of the EDX analysis was to characterise the mineral components present in each coal based on its metallic and non-metallic elements for a potential application. For each coal sample, the mapped zones in the SEM micrographs were scanned through the point ID technique. Consequently, the AZTEC EDX software (Oxford Instruments, UK) was executed to computationally elucidate the metallic and non-metallic elements of coal sample in weight percentage (wt\%) based on charge balance.

\subsubsection{Thermal analyses}

The thermal properties of the coals were examined by thermogravimetric (TG) analysis. For each TG test, about $12-15 \mathrm{mg}$ of each sample was placed in an alumina crucible and heated at $20^{\circ} \mathrm{C} / \mathrm{min}$ from room temperature (RT) to $900{ }^{\circ} \mathrm{C}$, based on the non-isothermal heating program of the TG thermal analyser (Shimadzu TG-50, Japan). For the non-oxidative characteristics tests, the TGA furnace was flushed with ultrapure nitrogen $\left(\mathrm{N}_{2}, 99.99 \%\right)$ gas at the flow rate of $100 \mathrm{~mL} / \mathrm{min}$ from ramp heating to the cooling stage of the process to maintain an inert environment for pyrolysis. In contrast, during the oxidative TGA, the furnace was flushed with air at the flow rate of $100 \mathrm{~mL} / \mathrm{min}$ from ramp heating to cooling to ensure an oxidative atmosphere for combustion. On completion, the raw TG data were converted in mass loss $(\%)$ and derivative mass loss $(\% / \mathrm{min})$ before plotting against temperature $\left({ }^{\circ} \mathrm{C}\right)$ in Microsoft Excel (version 2013) to determine the thermogravimetric (TG) and derivative thermogravimetric (DTG) plots. Subsequently, the temperature profile characteristics (TPC) of each sample were deduced using the data analysis feature of the Shimadzu software (Workstation TA-60WS, Japan). The TPCs deduced were; onset of ignition $\left(T_{\text {ons }}\right)$ temperature, midpoint $\left(T_{\text {mid }}\right)$ temperature, maximum or peak decomposition $\left(T_{\max }\right)$ temperature, and offset ( $\left.T_{\text {off }}\right)$ temperature. The ignition $\left(T_{\text {ons }}\right)$ temperature is deduced from the junction of the initial mass baseline and TGA curve tangent on the maximum gradient point. The midpoint $\left(T_{\mathrm{mid}}\right)$ temperature was determined from the halfway point on the tangent of the TGA curve. The offset $\left(T_{\text {off }}\right)$ temperature is deduced from the intersection of the TGA curve tangent on the maximum gradient point and the final mass baseline (ASTM E2550-17 2017; ISO 2014). Lastly, mass loss $\left(M_{\mathrm{L}}, \%\right)$ and residual mass $\left(R_{\mathrm{M}}, \%\right)$ was computed from the total mass loss and the final mass of each sample during TGA, respectively.

\subsubsection{Kinetic analyses}

The Coats-Redfern Model (CRM) was employed in this study to examine the kinetic parameters; activation energy $\left(E_{\mathrm{a}}\right)$ and pre-exponential factor $\left(k_{\mathrm{o}}\right)$ for the pyrolysis and combustion of the newly discovered coals in this study. The CRM is one of the most widely adopted integral graphical methods for examining the kinetic behaviour and decomposition mechanisms of thermally degrading materials in the literature (Coats and Redfern 1964). The theory of the CRM assumes that the thermal degradation of materials (e.g. coals) can be described by Eqs. (1)-(2):

$\frac{\mathrm{d} \alpha}{\mathrm{d} t}=k(T) f(\alpha)$

$\alpha=\frac{m_{o}-m_{\mathrm{t}}}{m_{o}-m_{\mathrm{f}}}$

The representative terms in Eqs. (1)-(2) namely; $\frac{\mathrm{d} \alpha}{\mathrm{d} t}$ represent the rate of reaction; $k$ is the reaction rate constant; $f(\alpha)$ is the reaction mechanism for the model, and $\alpha$ is the ratio of the mass ( $m_{\mathrm{o}}$-initial; $m_{\mathrm{t}}$ - fixed; and $m_{\mathrm{f}}$-final) of each thermally degraded coal sample during TGA. Consequently, the order of the reaction, $n$ is described by Eq. (3):

$f(\alpha)=(1-\alpha)^{n}$

The temperature of coal decomposition can be defined by the Arrhenius equation:

$k(T)=k_{\mathrm{o}} \exp \left(-\frac{E_{\alpha}}{R T_{\alpha}}\right)$

where, $k(T)$ is the rate-dependent temperature constant, $k_{o}$ is the pre-exponential factor $\left(\min ^{-1}\right) ; E_{\alpha}$ is the activation energy $(\mathrm{kJ} / \mathrm{mol}) ; R$ is the ideal gas constant $(\mathrm{J} / \mathrm{mol} \mathrm{K}) ; T$ is 
the absolute temperature (K). Consequently, Eqs. (3) and (4) are combined to obtain the relationship between the model reaction mechanism and the Arrhenius equation, which describes the thermal degradation of the sample during TGA. Hence, Eq. (5) is given as;

$\frac{\mathrm{d} \alpha}{\mathrm{d} t}=k_{\mathrm{d}} \exp \left(-\frac{E_{\alpha}}{R T_{\alpha}}\right)(1-\alpha)^{n}$

Typically, the thermal degradation of materials during TGA occurs at a pre-selected heating rate $(\beta)$. Therefore, the term $\beta$ is introduced to account for the effect of the heating rate $\frac{\mathrm{d} T}{\mathrm{~d} t}$ during TGA, as described in Eq. (6);

$\frac{\mathrm{d} \alpha}{\mathrm{d} T}=\frac{k_{\mathrm{o}}}{\beta} \exp \left(-\frac{E_{\alpha}}{R T_{\alpha}}\right)(1-\alpha)^{n}$

The thermal degradation of the coal samples at the preselected heating rate during the TGA process can consequently be deduced separation of variables, which results in the relation:

$\frac{\mathrm{d} \alpha}{(1-\alpha)^{n}}=\frac{k_{\mathrm{o}}}{\beta} \exp \left(-\frac{E_{\alpha}}{R T_{\alpha}}\right) \mathrm{d} T$

Equation (7) is subsequently integrated to deduce the integral function of the reaction model that describes the process of thermal degradation of each coal sample, which is given as:

$g(\alpha)=\int_{0}^{\alpha} \frac{d \alpha}{(1-\alpha)^{n}}=\frac{k_{\mathrm{o}}}{\beta} \int_{T_{0}}^{T} \exp \left(-\frac{E_{\alpha}}{R T_{\alpha}}\right) \mathrm{d} T$

The term $g(\alpha)$ signifies the integral function of the reaction model, which is adapted to Coats-Redfern model (CRM). Based on approximations in the CRM, Eq. (8) is revised to;

$\ln \left[\frac{g(\alpha)}{T^{2}}\right]=\ln \left[\frac{k_{\mathrm{d}} R}{\beta E_{\alpha}}\left(1-\frac{2 R T_{\alpha}}{E_{\alpha}}\right)\right]-\frac{E_{\alpha}}{R T_{\alpha}}$

The terms $\ln \left[\frac{k_{0} R}{\beta E_{\alpha}}\left(1-\frac{2 R T_{\alpha}}{E_{\alpha}}\right)\right]$ can be abridged to $\ln \left[\frac{k_{0} R}{\beta E_{\alpha}}\right]$ since $\left(1-\frac{2 R T_{\alpha}}{E_{\alpha}}\right)$ tend to unity. Hence, Eq. (10) is derived to describe the kinetics of the thermal degradation of each coal:

$\ln \left[\frac{g(\alpha)}{T^{2}}\right]=\ln \left[\frac{k_{0} R}{\beta E_{\alpha}}\right]-\frac{E_{\alpha}}{R T_{\alpha}}$

Based on the high rates of the coal conversions during TG in this study, the first-order reaction model was selected to simply the kinetic analysis. Hence, Eq. (10) was revised to:

$\ln \left[\frac{-\ln (1-\alpha)}{T^{2}}\right]=\ln \left[\frac{k_{\mathrm{o}} R}{\beta E_{\alpha}}\right]-\frac{E_{\alpha}}{R T_{\alpha}}$
Based on Eq. (11), the kinetic parameters $E_{\alpha}$ and $k_{\mathrm{o}}$ can be derived from the slope $-\frac{E_{\alpha}}{R}$ and intercept $\ln \left[\frac{k_{0} R}{\beta E_{\alpha}}\right]$ of the straight-line plots of $\ln \left[\frac{-\ln (1-\alpha)}{T^{2}}\right]$ against $\frac{1000}{T}$ based on the governing equations and mechanism of thermal degradation based on the Coats-Redfern Model. Hence, the terms $E_{\alpha}$ and $k_{\mathrm{o}}$ describe the kinetics of coal degradation based on conversion degree $(\alpha)$, temperature $(T)$, and time ( $t$ ) during TGA.

\section{Results and discussion}

\subsection{Physicochemical properties}

Table 1, presents the physicochemical properties of the AKZ, OME, and SHG coals. The ultimate analysis indicates that the coal samples contain the following range of elements: Carbon (C), 47.62wt\%-64.35 wt\%; Hydrogen (H), 4.13 wt\%-5.55 wt\%; Nitrogen (N), 1.12 wt\%$1.40 \mathrm{wt} \%$; Sulphur (S), $0.57 \mathrm{wt} \%-0.69 \mathrm{wt} \%$; and Oxygen (O), $28.01 \mathrm{wt} \%-46.56 \mathrm{wt} \%$. The highest $\mathrm{C}$ and $\mathrm{H}$ were observed in SHG coal sample, while the lowest values were observed in AKZ. Furthermore, the $\mathrm{N}$ and $\mathrm{S}$ content indicate the conversion of the coals examined could potentially generate hazardous emissions of nitrous $\left(\mathrm{NO}_{x}, \mathrm{NH}_{x}\right)$ and sulphurous $\left(\mathrm{SO}_{x}, \mathrm{H}_{x} \mathrm{~S}\right.$ where $\left.x=1,2, \ldots, n\right)$ gases during thermal conversion. In addition, the high carbon could potentially result in high emissions of greenhouse gases such as carbon dioxide $\left(\mathrm{CO}_{2}\right)$ and carbon monoxide $(\mathrm{CO})$. The thermal conversion of coal and its associated greenhouse gas (GHG) emissions are potentially dangerous to human health, safety, and environment particularly exacerbating climate change and global warming (Reddy 2013). Hence, strategic measures that ensure high efficiency and low emissions are required to design and develop future power plants based on the coals examined in this study.

Proximate analysis showed the coal samples contain the following range of properties: Moisture (M), $6.00 \mathrm{wt} \%$ $6.35 \mathrm{wt} \%$; volatile matter (VM), $26.18 \mathrm{wt} \%-37.74 \mathrm{wt} \%$; Ash (A), $9.45 \mathrm{wt} \%-11.59 \mathrm{wt} \%$; and fixed carbon (FC), $44.80 \mathrm{wt} \%-58.38 \mathrm{wt} \%$. The highest moisture content was observed in OME coal, whereas the lowest was in AKZ coal. The moisture content of coal is an important parameter that affects its ignitability and potential utilisation (Speight 2012). Typically, the processing and utilisation of coal are hampered by high moisture content. In this study, the moisture content of below $10 \%$ observed for all the coal samples are within the acceptable limits for electric power generation (Chukwu et al. 2016) or thermochemical conversion into value-added products (Akinyemi et al. 2020a). In contrast, the volatile matter (VM) is an important factor 
Table 1 Physicochemical fuel properties of the coals

\begin{tabular}{lllllllllll}
\hline Coal & $\mathrm{C}(\mathrm{wt} \%)$ & $\mathrm{H}(\mathrm{wt} \%)$ & $\mathrm{N}(\mathrm{wt} \%)$ & $\mathrm{S}(\mathrm{wt} \%)$ & $\mathrm{O} *(\mathrm{wt} \%)$ & $\mathrm{M}(\mathrm{wt} \%)$ & $\mathrm{VM}(\mathrm{wt} \%)$ & $\mathrm{A}(\mathrm{wt} \%)$ & $\mathrm{FC} *(\mathrm{wt} \%)$ & $\mathrm{HHV}(\mathrm{MJ} / \mathrm{kg})$ \\
\hline $\mathrm{AKZ}$ & 47.62 & 4.13 & 1.12 & 0.57 & 46.56 & 6.00 & 26.18 & 9.45 & 58.38 & 18.65 \\
$\mathrm{OME}$ & 58.31 & 5.02 & 1.31 & 0.66 & 34.69 & 6.35 & 32.18 & 11.59 & 49.88 & 24.17 \\
SHG & 64.35 & 5.55 & 1.40 & 0.69 & 28.01 & 6.23 & 37.74 & 11.24 & 44.8 & 26.59 \\
\hline
\end{tabular}

Coal sample codes: Akunza (AKZ); Ome (OME) and Shiga (SHG). Element codes: Carbon (C); Hydrogen (H); Nitrogen (N); Sulphur (S); Oxygen (O)*; Moisture (M); Volatile Matter (VM); Ash (A); Fixed Carbon (FC)*; and Higher Heating Value (HHV). *Determined by difference

for determining not only the coal rank (Speight 2012) but also its suitability for potential energy recovery through pyrolysis (carbonisation), combustion or gasification (Nyakuma et al. 2018).

The findings also showed that AKZ contains the highest fixed carbon (FC) content, which is typically inversely proportional to the VM content. The FC of coal is a measure of the estimated coke yield after devolatilization from carbonisation or slow pyrolysis (Nyakuma 2016). Furthermore, the highest AC was observed in OME coal, whereas the lowest was observed in AKZ. Typically, ash represents the bulk mineral matter, inorganic or non-combustible residue arising from the coal combustion, which has potential impacts on the environment (Akinyemi et al. 2020b). The analysis of the chemical composition of ash in coal is crucial to the conversion process (Cebeci et al. 2002). This is due to the effect of coal ash on the slagging, agglomeration or viscosity of bed materials (Özer et al. 2017). Based on the foregoing, it can reasonably be surmised that OME could pose more ash related problems compared to SHG and AKZ during combustion.

The higher heating value (HHV) of the coals ranged from 18.65 to $26.59 \mathrm{MJ} / \mathrm{kg}$, with the SHG sample reporting the highest value while the AKZ reported the lowest value. The HHV is a measure of the heat content or energy value of any coal sample (Speight 2012). It is one of the most important fuel properties of coal typically employed to evaluate the rank, classification, and suitability for various applications (ASTM D388-12 2012). Based on the HHV, AKZ coal sample could be classified as Lignitic class or Lignite A coal with heating values typically in the range of $14.70-19.30 \mathrm{MJ} / \mathrm{kg}$. The OME coal sample with its HHV of $24.17 \mathrm{MJ} / \mathrm{kg}$ could be ranked as Subbituminous or specifically classified as Subbituminous B coal, which exhibits HHV from 22.10 to $24.40 \mathrm{MJ} / \mathrm{kg}$. However, the SHG coal sample could be classified high-volatile C Bituminous agglomerating coal or Subbituminous A nonagglomerating coal, with HHVs typically ranging from 24.40 to $26.70 \mathrm{MJ} / \mathrm{kg}$ (Speight 2012).

\subsection{Microstructure properties}

The SEM micrographs and EDX spectra in Figs. 3-5 present insights into the surface morphology, microstructure, and chemistry of the constituent elements of the coal samples. For all the coal samples, the SEM micrographs displayed particles with rough textures and surfaces characterised by a distinct glassy sheen, which is typically ascribed to the presence of metallic elements, minerals, or aluminosilicates such as quartz and kaolinite (Karayigit et al. 2001). The coal particles also exhibited close-packed stratified layers of materials with contoured outlines, which may be due to the deposition of organic materials during the coalification process. Lastly, the particles were found to be devoid of surface pores or crevices, which indicate a dense, compact and sintered microstructure.

\subsection{Mineralogical properties}

The mineralogical properties of AKZ, OME, and SHG were examined by energy-dispersive X-ray (EDX) spectroscopy, as shown in Table 2. The EDX mineralogical analysis was carried out to characterise the mineral components present in each coal based on its metallic and nonmetallic elements for potential applications.

The elements detected in the coal samples were; Aluminium $(\mathrm{Al})$, Carbon $(\mathrm{C})$, Calcium $(\mathrm{Ca})$, Copper $(\mathrm{Cu})$, Iron $(\mathrm{Fe})$, Potassium $(\mathrm{K})$, Magnesium $(\mathrm{Mg})$, Oxygen $(\mathrm{O})$, Sulphur (S), Silicon (Si), and Titanium (Ti) at various concentrations. For all samples, the major elements detected were $\mathrm{C}, \mathrm{O}, \mathrm{Si}$, and $\mathrm{Al}$, whereas $\mathrm{Ca}, \mathrm{Cu}, \mathrm{Fe}, \mathrm{K}, \mathrm{Mg}, \mathrm{S}$, and $\mathrm{Ti}$ were detected in minor proportions. It is vital to state that Sulphur and Potassium were undetected in OME and SHG, respectively. Typically, the occurrence of metals is related to the clay, salt, or the porphyrin constituents in the coal structure, which also serve as a measure of the level of coalification (Speight 2012).

For all cases, the major elements detected as defined by composition $>2.50 \mathrm{wt} \%$, were in the order $\mathrm{C}>\mathrm{O}>$ $\mathrm{Si}>\mathrm{Al}$. The highest composition of $\mathrm{C}$ was detected in SHG, whereas the lowest was observed in OME. In contrast, the highest and lowest compositions of $\mathrm{O}$ were 

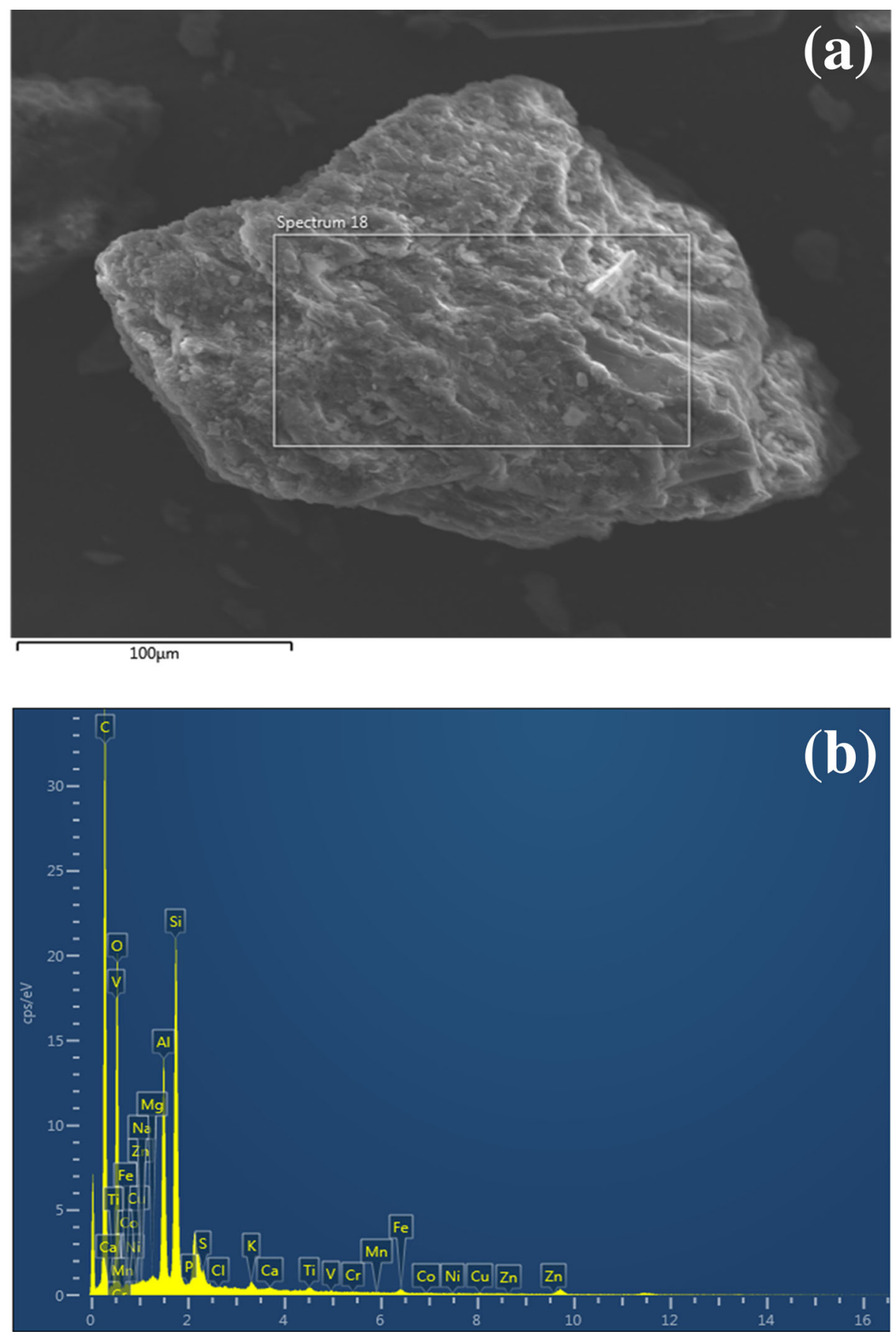

Fig. 3 SEM/EDX micrograph of Akunza (AKZ) Coal

observed in AKZ and SHG, respectively. The higher $\mathrm{C}$ but lower O content of SHG compared to the other coal samples accounts for its high calorific value $(26.59 \mathrm{MJ} / \mathrm{kg}$ ) as reported in Table 1. Hence, the results of the mineralogical study are consistent with the physicochemical analyses. The highest composition of $\mathrm{Si}$ was observed in OME, whereas the lowest was in SHG. Typically, Si exists as silicon dioxide $\left(\mathrm{SiO}_{2}\right)$ otherwise termed quartz in coal (Speight 2012), which accounts for $40 \%-90 \%$ of the major inorganic components and combustion residues found in coal ash (Wong et al. 2020). Quartz is the primary constituent of various granite, quartz, porphyry, and rhyolite rocks (Speight 2012), and tends to occur due to proximity to coal beds during the process of silicate weathering or coalification (Akinyemi et al. 2020b). Hence, the high Si indicates the presence of $\mathrm{SiO}_{2}$ in OME, which is in good agreement with the high ash content of OME as earlier reported in Table 1. 

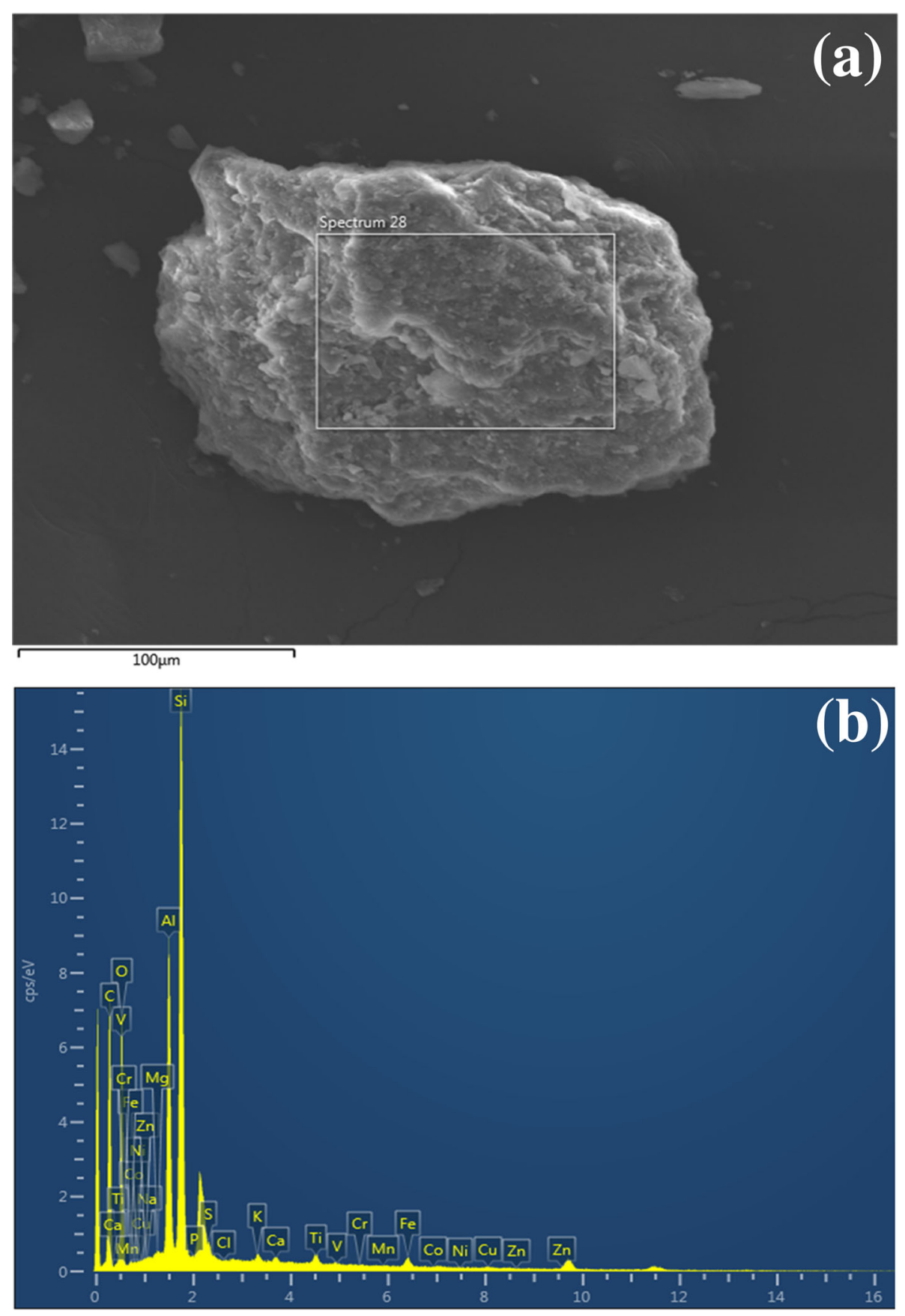

Fig. 4 SEM/EDX micrograph of Ome (OME) Coal

Similarly, the highest composition of Al was observed in OME, whereas SHG contains the lowest composition. Typically, $\mathrm{Si}$ and $\mathrm{Al}$ exist as clay minerals or aluminosilicates, which account for the highest inorganic constituents of coal (Gluskoter 1975). Furthermore, Al and Si also suggest the presence of carbonaceous and quartz minerals such as clay (Sellaro et al. 2015). The most common clay minerals are kaolinite, illite, chlorite, sericite, and montmorillonite (Liu and Peng 2015). The clay found in coals is a significant contributor to ash formation, loss of calorific value, and increased cost of ash handling/disposal during the combustion of coal in power plants (Spears 2000). Lastly, the presence of clay minerals along with other metal elements such as Ti and Fe (Sengupta et al. 2008) may account for the distinct lustre observed in the coals, as reported earlier in our previous study (Nyakuma et al. 2019b). In general, the minor elements detected were in the order $\mathrm{Fe}>\mathrm{K}>\mathrm{Ti}>\mathrm{Cu}>\mathrm{Ca}>\mathrm{Mg}>\mathrm{S}$ particularly for 

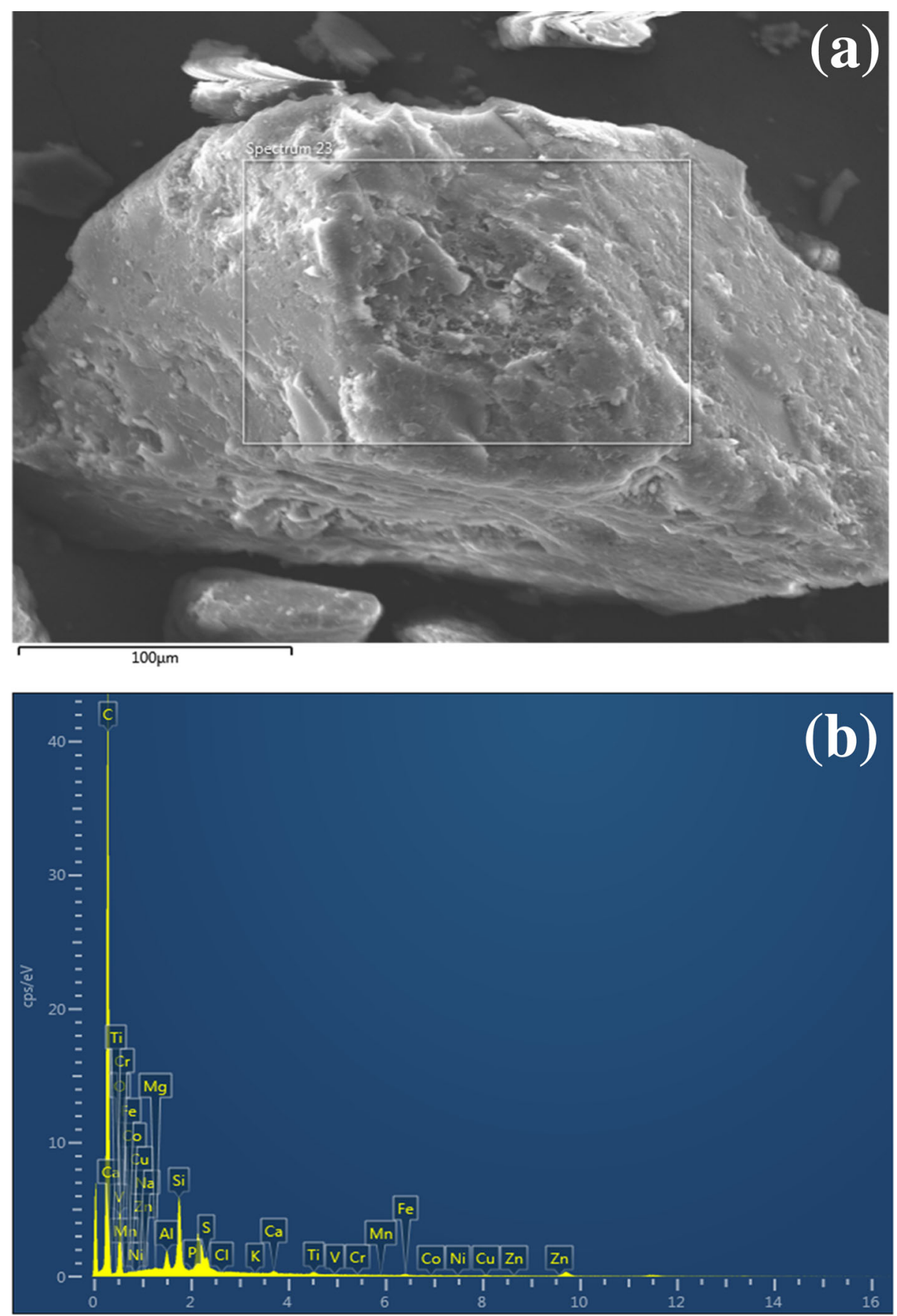

Fig. 5 SEM/EDX micrograph of Shiga (SHG) Coal

Table 2 Elemental compositions (wt $\%$ ) of AKZ, OME, SHG coal samples by EDX analysis

\begin{tabular}{llllllllllrr}
\hline Coal sample & $\mathrm{Al}$ & $\mathrm{C}$ & $\mathrm{Ca}$ & $\mathrm{Cu}$ & $\mathrm{Fe}$ & $\mathrm{K}$ & $\mathrm{Mg}$ & $\mathrm{O}$ & $\mathrm{S}$ & $\mathrm{Si}$ & $\mathrm{Ti}$ \\
\hline AKZ & 3.94 & 57.26 & 0.07 & 0.09 & 0.35 & 0.20 & 0.06 & 31.78 & 0.05 & 6.00 & 0.19 \\
OME & 6.57 & 49.33 & 0.23 & 0.24 & 1.07 & 0.25 & 0.07 & 29.16 & 0.00 & 12.51 & 0.58 \\
SHG & 0.72 & 76.67 & 0.16 & 0.24 & 0.26 & 0.00 & 0.05 & 18.88 & 0.18 & 2.59 & 0.24
\end{tabular}

Coal sample codes: Akunza (AKZ); Ome (OME) and Shiga (SHG). Element codes: Aluminium (Al); Carbon (C); Calcium (Ca); Copper (Cu); Iron (Fe); Potassium (K); Magnesium (Mg); Oxygen (O); Sulphur (S); Silicon (Si) and Titanium (Ti) 
AKZ. For OME no sulphur (S) was detected and the composition of $\mathrm{Ti}>\mathrm{K}$, whereas for $\mathrm{SHG}$ no $\mathrm{K}$ was detected and the composition of $\mathrm{S}>\mathrm{Ca}$. The highest composition of $\mathrm{Fe}, \mathrm{Ti}, \mathrm{K}, \mathrm{Ca}$, and $\mathrm{Mg}$ was detected in OME, which indicates high mineral compositions of pyrite $\left(\mathrm{FeS}_{2}\right)$, anastase or ilmenite $(\mathrm{Ti})$, illite $(\mathrm{K})$, calcite $\left(\mathrm{CaCO}_{3}\right)$, and oxides of $\mathrm{Mg}$.

\subsection{Thermal properties}

The thermal properties of AKZ, OME, and SHG were examined under oxidative and non-oxidative conditions based on non-isothermal heating to examine the burning (combustion, CMB) and devolatilization (pyrolysis, PYR) profiles of the coal samples, as depicted in Figs. 6 and 7, respectively.

The burning and devolatilization profiles of the coals depicted in the TG plots showed the typical downward " $Z$ " curves, which slope from left to right for most thermally degrading carbonaceous materials. The findings indicate that the non-isothermal increase in temperatures from 30 to $900{ }^{\circ} \mathrm{C}$ resulted in significant thermal degradation during TGA. The burning profiles (Fig. 6) exhibited steeper plots particularly from 300 to $500{ }^{\circ} \mathrm{C}$ compared to the devolatilization profiles (Fig. 7). The steeper TG plots (Fig. 6) observed for the burning profiles indicate significantly higher thermal degradation, loss of mass, and massloss rates for the coals compared to the devolatilization process. This observation could be ascribed to the exothermic nature of the oxidative (combustion) process, which ensures the higher heat or thermal energy supply to the coal particles during the TG degradation process. The thermal degradation of the coals observed during TGA could also be ascribed to the degradation of the organic fractions or maceral components. The term macerals describe the microscopic and rock-rich constituents of coal comprising the vitrinite, inertinite, and liptinite groups. Typically, the compositions range from $50 \%$ to $90 \%$ for vitrinites, $5 \%-10 \%$ for liptinites, and $50 \%-70 \%$ for the inertinites depending on the rank, classification, and source of the coal (Speight 2012). Furthermore, the macerals are comprised of polymers, lignin, cellulose, resins, spores, and cuticles derived from plants, algae, and fungi residues (Xie et al. 2013). Hence, the loss of mass during TGA could be ascribed to the thermal degradation of plant cell wall matter (or organic fractions) present in the coal samples. The findings of Košina and Heppner (1984) and Landais et al. (1989) demonstrated that the degree of the thermal degradation, physicochemical behaviour, and potential conversion products greatly depends on the maceral composition, rank, and atomic ratios of coals. Hence, the effect of the oxidising and non-oxidising environments on the thermal degradation of AKZ, OME, and SHG was examined by temperature profile characterization. Table 3 presents the temperature profile characteristics (TPCs) of the coals under oxidative (combustion) and non-oxidative (pyrolysis) conditions during TGA.

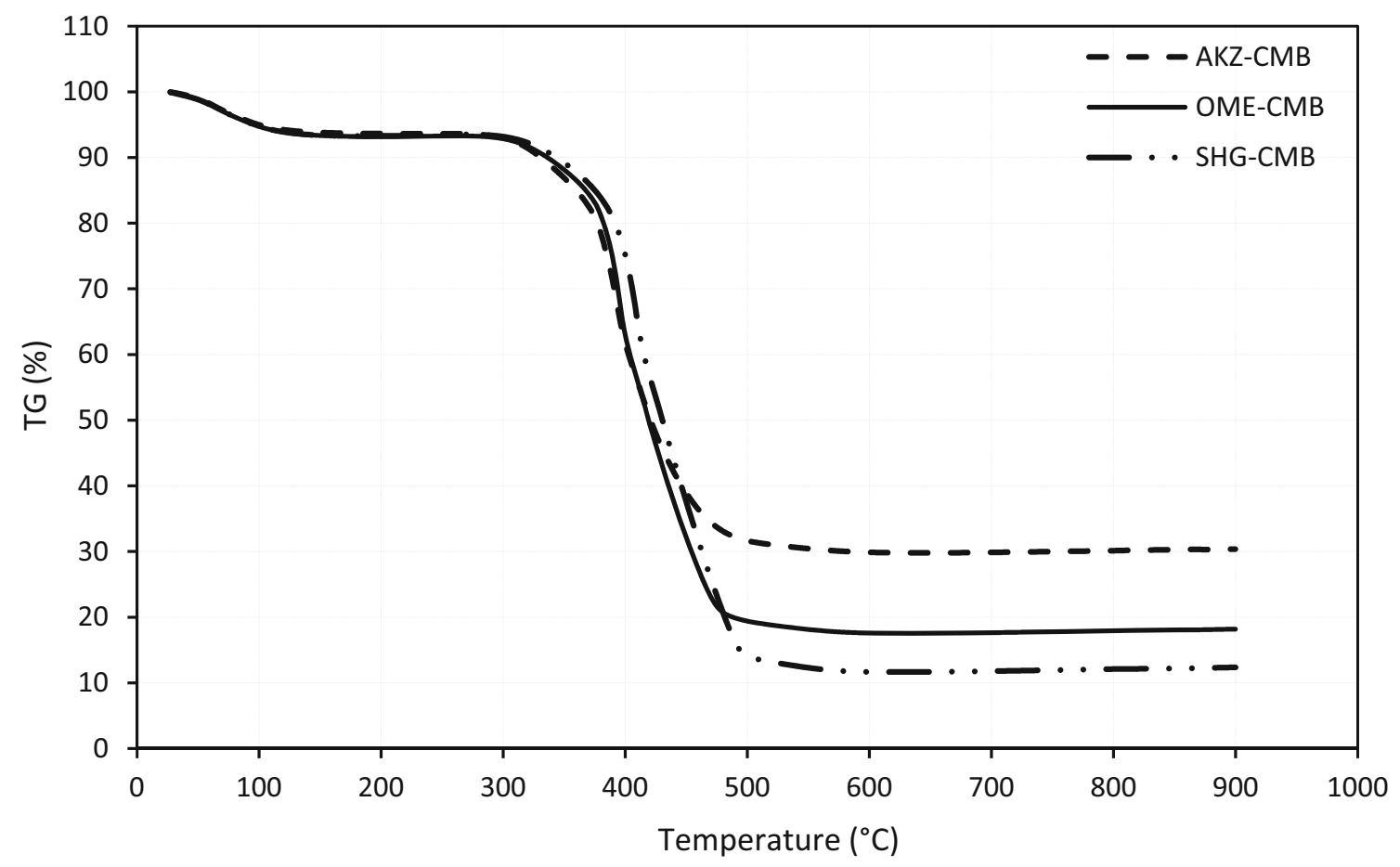

Fig. 6 TG burning profile (CMB) plots for AKZ, OME, and SHG 


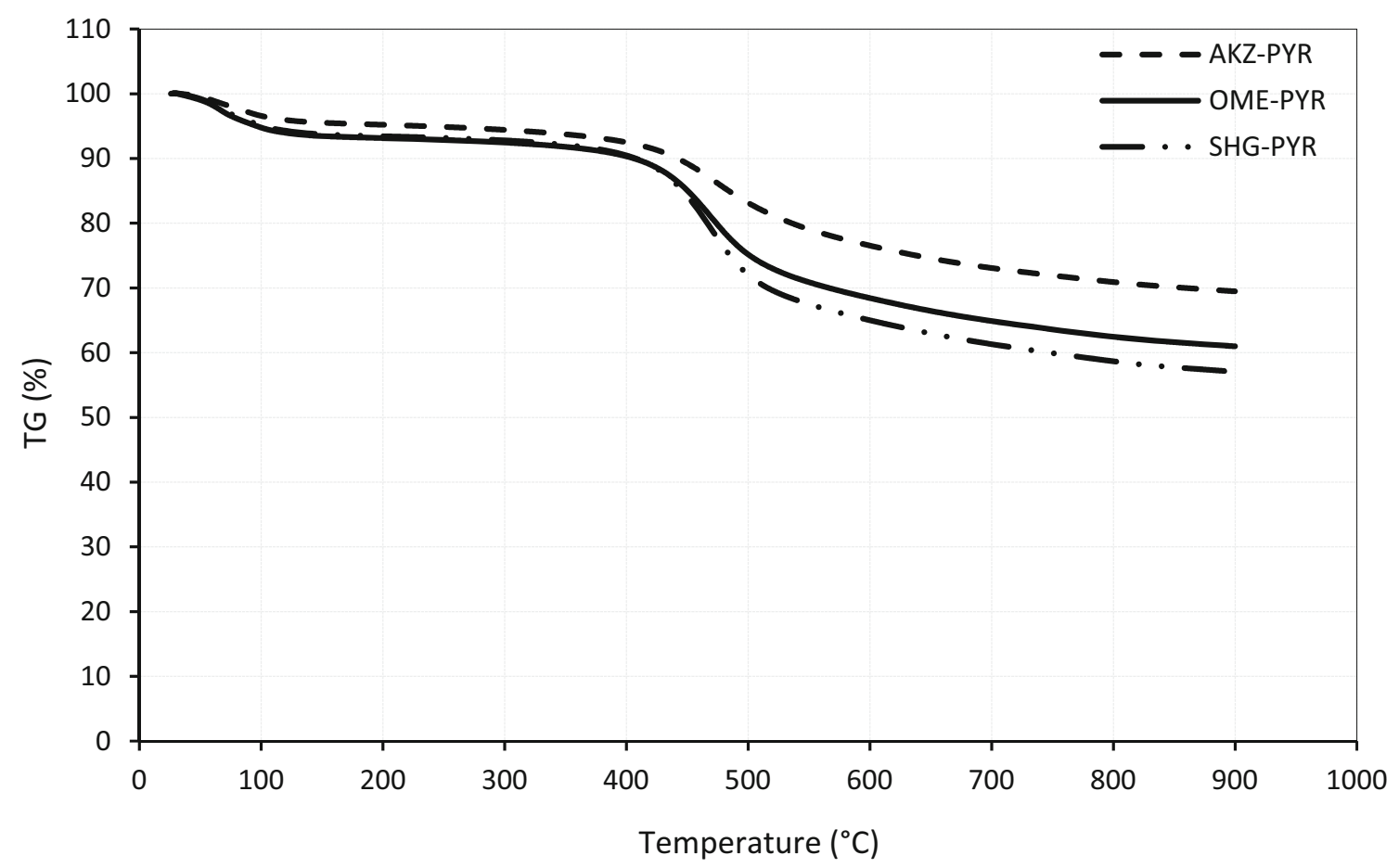

Fig. 7 TG devolatilization profile (PYR) Plots for AKZ, OME, and SHG

Table 3 TG plot-temperature profiles characteristics of the coal samples

\begin{tabular}{lllllll}
\hline Coal sample & Reaction/process & \multicolumn{2}{l}{ Temperatures $\left({ }^{\circ} \mathrm{C}\right)$} & \multicolumn{2}{c}{ Mass loss $\left(M_{\mathrm{L}}, \%\right)$} & Residual mass $\left(R_{\mathrm{M}}, \%\right)$ \\
\cline { 3 - 6 } & & & Onset $\left(T_{\text {ons }},{ }^{\circ} \mathrm{C}\right)$ & Midpoint $\left(T_{\text {mid }},{ }^{\circ} \mathrm{C}\right)$ & Endset $\left(T_{\text {off }},{ }^{\circ} \mathrm{C}\right)$ & \\
\hline AKZ & \multirow{2}{*}{ Combustion } & 349.64 & 395.95 & 436.66 & 69.61 & 30.40 \\
OME & & 361.05 & 405.59 & 440.24 & 81.71 & 18.29 \\
SHG & & 374.93 & 421.12 & 459.39 & 87.57 & 12.44 \\
AKZ & \multirow{2}{*}{ Pyrolysis } & 363.35 & 480.98 & 594.32 & 30.51 & 69.49 \\
OME & & 385.95 & 468.24 & 556.11 & 39.04 & 60.96 \\
SHG & & 468.55 & 543.03 & 43.05 & 56.95 \\
\hline
\end{tabular}

As observed, the oxidative conditions resulted in a high loss of mass ranging from $69.61 \%$ for AKZ to $87.57 \%$ as observed for SHG. Due to the oxidative nature of the process, it can be reasonably inferred that the mass loss during the process results in flue gas mixture along with coke and ash, which are collectively termed the residual mass. In this study, the residual masses for the oxidative process ranged from $12.44 \%$ to $30.40 \%$ as observed for SHG and AKZ, respectively. Compared to the ash contents of the coals in Table 1, it can be reasonably surmised that the residual mass comprises of principally ash $(9.45 \mathrm{wt} \%$ to $11.59 \mathrm{wt} \%$ ) along with the coke or unreacted coal particles arising from incomplete TGA combustion. Hence, higher temperatures (above $900{ }^{\circ} \mathrm{C}$ ), longer residence and isothermal conditions are required for complete combustion of the coals.

For the non-oxidative conditions, the mass loss ranged from $30.51 \%$ for $\mathrm{AKZ}$ to $43.05 \%$ as observed for $\mathrm{SHG}$, which resulted in the residual mass ranging from $56.95 \%$ for SHG to $69.49 \%$ for AKZ. Based on the nature of the process, the predicted products of the mass loss could be pyrolysis gas (fuel gases), oil, and tar, whereas the solid products could be largely coke, char and ash. This view is corroborated by Sun et al. (2003) who examined the pyrolysis behaviour of Shenmue coals. The findings showed that coal pyrolysis resulted in light hydrocarbons $\left(\mathrm{C}_{1}-\mathrm{C}_{4}\right)$, aromatic hydrocarbons $\left(\mathrm{C}_{6}-\mathrm{C}_{8}\right)$ along with carbon dioxide $\left(\mathrm{CO}_{2}\right)$, water vapour $\left(\mathrm{H}_{2} \mathrm{O}\right)$ and other pyrolysis gases due to the thermal degradation of macerals such as 
vitrinite and inertinite. Furthermore, the yield and composition of the pyrolysis product gas are significantly dependent on the reactivity of the macerals (Sun et al. 2003). Similarly, Zhao et al. (2011) employed TG-MS and a fixed bed reactor to examine the pyrolytic decomposition behaviour of Pingshuo coal. The findings indicated that pyrolysis of coals is largely dependent on the reactivity of individual macerals particularly inertinite compared to vitrinite. Furthermore, the study showed that the distribution of pyrolysis products is comprised of tar, fuels gas, and char. These findings are corroborated by Zou et al. (2017) whose study showed that coal pyrolysis results in a fuel gas mixture comprising; hydrogen $\left(\mathrm{H}_{2}\right)$, carbon dioxide $\left(\mathrm{CO}_{2}\right)$, carbon monoxide $(\mathrm{CO})$, methane $\left(\mathrm{CH}_{4}\right)$ and water vapour $\left(\mathrm{H}_{2} \mathrm{O}\right)$ and ethylene $\left(\mathrm{C}_{2} \mathrm{H}_{2}\right)$ based on the TG-MS and gas evolution.

Overall, the mass losses for the oxidative process in this study are higher than the non-oxidative process, whereas the residual masses were higher during the non-oxidative compared to the oxidative processes. The plausible explanation can be found in the higher thermal energy and exothermic nature of the oxidative process, which provides the sufficiently higher heat required to break the bonds of the macerals in the coal structure. This assertion is verified by the higher mass-loss rates observed during the oxidative thermal degradation $(17.70-19.91 \% / \mathrm{min})$ compared to the non-oxidative process $(2.26-5.3 \% / \mathrm{min})$ along with other TPC values shown in Table 3 .

Furthermore, the onset or ignition $\left(T_{\text {ons }}\right)$ temperatures (Table 3) for the oxidative coal degradation processes commenced from $349.64{ }^{\circ} \mathrm{C}$ (AKZ) to $374.93{ }^{\circ} \mathrm{C}$ (SHG), whereas the values for the non-oxidative process occurred between $363.35{ }^{\circ} \mathrm{C}$ (AKZ) and $391.13{ }^{\circ} \mathrm{C}$ (SHG). The endset or burnout $\left(T_{\text {off }}\right)$ temperatures for the oxidative coal degradation processes occurred from $436.66{ }^{\circ} \mathrm{C}$ (AKZ) to $459.39{ }^{\circ} \mathrm{C}$ (SHG), whereas the values for the non-oxidative process occurred between $543.03{ }^{\circ} \mathrm{C}$ (SHG) and $594.32{ }^{\circ} \mathrm{C}$ (AKZ). For all cases, the TPC values $T_{\text {ons }}, T_{\text {mid }}$ and $T_{\text {off }}$ were higher for the non-oxidative degradation of the coals compared to the oxidative process. As earlier surmised, this is due to the exothermic nature of the oxidative process, which provides higher heating energy and hence higher mass-loss rates required to thermally degrade the coal components compared to the non-oxidative process during TGA. Furthermore, the oxidative reaction conditions provide suitable conditions for the secondary cracking or thermal degradation of condensable products, char or coke produced during the TGA process.

The degradation pathway for the oxidative and nonoxidative thermal degradation of the coals was examined by derivative thermogravimetry (DTG) plots, as shown in Figs. 8 and 9.
The DTG plots in Figs. 8 and 9 each reveal two sets of symmetric and asymmetric peaks. The first sets of smaller peaks occurred from 30 to $200{ }^{\circ} \mathrm{C}$ for the oxidative and non-oxidative processes, whereas the second larger set of peaks were from 200 to $500{ }^{\circ} \mathrm{C}$ for the oxidative and 200-600 ${ }^{\circ} \mathrm{C}$ for the non-oxidative thermal degradation. The non-oxidative process occurred over a wider temperature range compared to the oxidative process. This is verified by the temperature difference of the $T_{\text {ons }}$ and $T_{\text {off }}$ for the non-oxidative thermal degradation, which was; $230.97{ }^{\circ} \mathrm{C}, 170.16^{\circ} \mathrm{C}$, and $151.90{ }^{\circ} \mathrm{C}$ for AKZ, OME, and SHG, respectively, compared to $87.02{ }^{\circ} \mathrm{C}, 79.19^{\circ} \mathrm{C}$, and $84.46{ }^{\circ} \mathrm{C}$ for the oxidative process.

The peaks for the oxidative process were found to be asymmetric with shoulder protuberances on the left-hand side of the large peak between 300 and $350{ }^{\circ} \mathrm{C}$ for all samples and between 400 and $450{ }^{\circ} \mathrm{C}$ on the right-hand side for the OME and SHG coal samples. In contrast, the non-oxidative process resulted in symmetric peaks devoid of shoulder peaks between 200 and $600{ }^{\circ} \mathrm{C}$. Furthermore, the observed peaks for the non-oxidative process exhibited lower derivative mass-loss rates (Table 4) and significantly smaller peaks from 200 to $600{ }^{\circ} \mathrm{C}$ compared to the oxidative process. This observation indicates the devolatilization process that governs thermal degradation and softening is largely endothermic (Agroskin et al. 1972), as similarly reported in the literature (Hanrot et al. 1994).

Based on the thermal degradation ranges, peak sizes and symmetry, the oxidative and non-oxidative thermal degradation processes occurred in three stages. The first stage could be ascribed to drying or loss of coal surface moisture along with low molecular weight volatile components below $200{ }^{\circ} \mathrm{C}$ (Xie et al. 2013). Zou et al. (2017) reported that the loss of mass during this stage of coal degradation is also ascribed to the evolution of moisture, free radical groups, and hydrogen $\left(\mathrm{H}_{2}\right)$. Accordingly, the second stage observed between 200 and $500{ }^{\circ} \mathrm{C}$ and from 200 to $600{ }^{\circ} \mathrm{C}$ for the oxidative and non-oxidative processes, respectively, could be attributed to the bond cleavage or cracking of tar along with the evaporation and transport of evolved gases during the thermal degradation of coal macromolecules (Zou et al. 2017). Likewise, this stage could also be due to the thermal degradation of coal components such as macerals, as earlier surmised. Hence, the mass loss during the TGA of the coals in this study could be largely due to vitrinite, which is the most abundant maceral fraction compared to inertinite and liptinite in decreasing order. In addition, the high temperature (typically $400-800{ }^{\circ} \mathrm{C}$ ) degradation of coal is considered an exothermic process mostly due to vitrinite degradation alongside coke graphitization (Xie et al. 2013) and contraction due to dehydrogenation of organic matter (Landais 


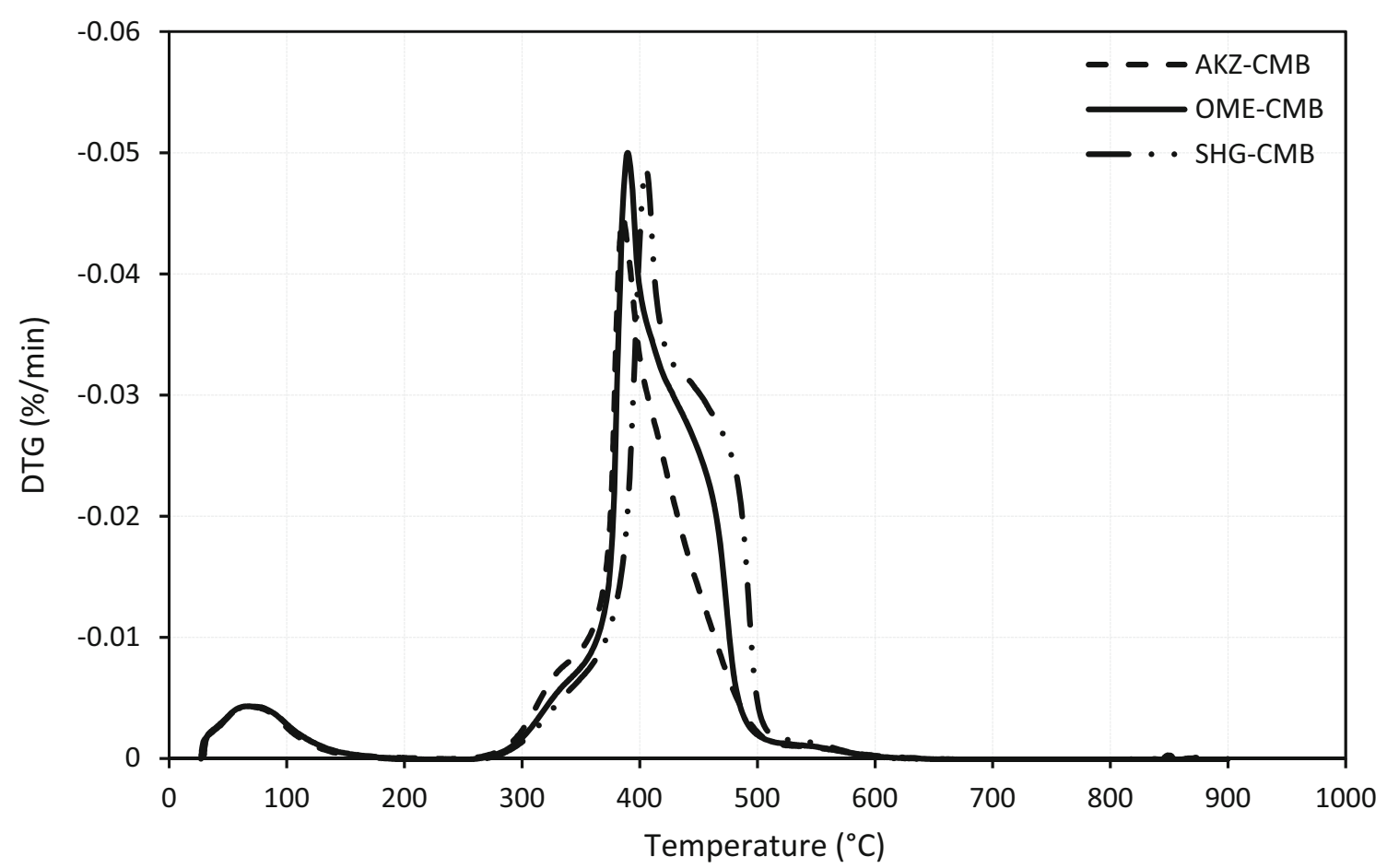

Fig. 8 DTG plots for the burning profiles (CMB) of AKZ, OME, and SHG

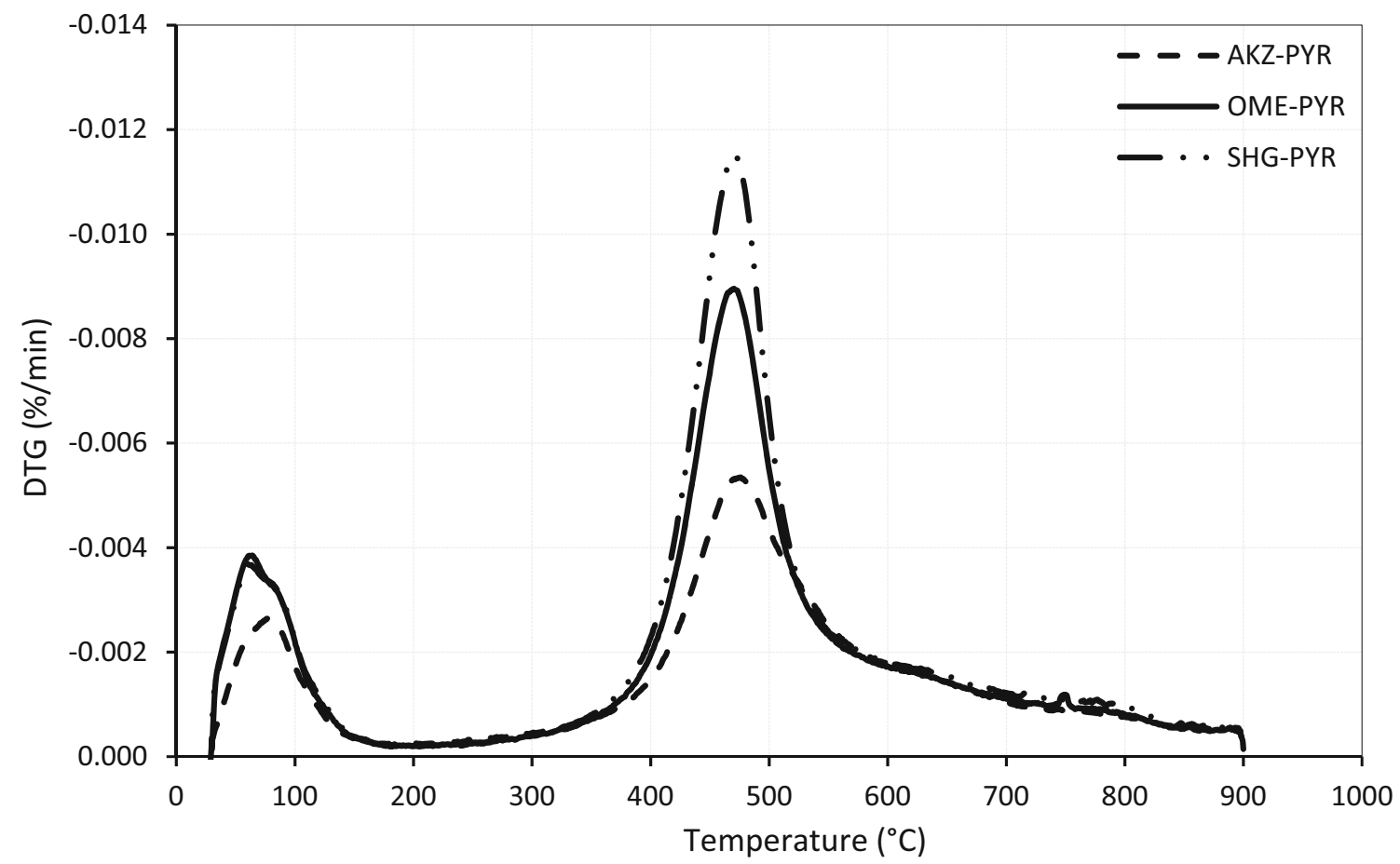

Fig. 9 DTG plots for devolatilization (PYR) of AKZ, OME, and SHG

et al. 1989). Consequently, the thermal conductivity of the coal increases resulting in enhanced fluidity, swelling, and meta-plasticity (Strezov et al. 2007; Xie et al. 2013). However, the mass loss during thermal degradation in the range $200{ }^{\circ} \mathrm{C}<x<400{ }^{\circ} \mathrm{C}$ was previously ascribed to the degradation of inertinite macerals, which occurs at low temperatures in the coal structure (Xie et al. 2013). Landais et al. (1989) reported the low reactivity of inertinite to degradation in the range of $350{ }^{\circ} \mathrm{C}$ and $375^{\circ} \mathrm{C}$ under pyrolysis conditions. Typically, the weight loss path and 
Table 4 DTG plot-temperature profiles characteristics

\begin{tabular}{llllll}
\hline Coal sample & Reaction & Peak drying temp $\left({ }^{\circ} \mathrm{C}\right)$ & Drying rate $(\% / \mathrm{min})$ & Peak devolatilization temp $\left({ }^{\circ} \mathrm{C}\right)$ & Devolatilization rate $(\% / \mathrm{min})$ \\
\hline AKZ & Combustion & 65.87 & 1.71 & 385.44 & 17.7 \\
OME & & 67.83 & 1.62 & 389.80 & 19.91 \\
SHG & & 1.62 & 405.26 & 19.3 & 2.26 \\
AKZ & Pyrolysis & 77.27 & 1.26 & 475.95 & 4.02 \\
OME & & 63.97 & 1.82 & 470.29 & 5.13 \\
SHG & & 60.38 & 4.79 & 470.67 & \\
\hline
\end{tabular}

mechanism during high-temperature coal degradation proceeds from inertinite to vitrinite and lastly liptinite (Landais et al. 1989). The last stage $\left(>500{ }^{\circ} \mathrm{C}\right.$ and $600{ }^{\circ} \mathrm{C}$ ) resulted in low mass losses for both oxidative and nonoxidative processes as evident in the tailing (mass loss plateaux) observed in Figs. 8 and 9. Various researchers have attributed the mass loss in this region to the decomposition of mineral matter and condensation of aromatic rings due to secondary degassing reactions, which occur at high temperatures (Zou et al. 2017).

The temperature profiles characteristics (TPC) for the DTG plots were deduced to examine the reactivity, mechanism, and mass-loss rates for the drying and devolatilization processes under oxidative and non-oxidative conditions, as presented in Table 4. For all cases, the peak drying temperatures were observed from $60.38{ }^{\circ} \mathrm{C}$ (SHG) to $77.27{ }^{\circ} \mathrm{C}$ (AKZ) for the non-oxidative process compared to the oxidative process, which was observed from $65.87{ }^{\circ} \mathrm{C}$ (AKZ) to $68.27{ }^{\circ} \mathrm{C}$ (SHG). However, mass loss rates for both oxidative and non-oxidative conditions were similar indicating the reactivity of the coals was similar during the drying stage. However, the peak devolatilization temperatures were observed from $470.29{ }^{\circ} \mathrm{C}$ (OME) to $475.95{ }^{\circ} \mathrm{C}$ (AKZ) for the non-oxidative process compared to the oxidative process, which was from $385.44{ }^{\circ} \mathrm{C}$ (AKZ) to $405.26{ }^{\circ} \mathrm{C}$ (SHG). However, the mass-loss rates for both oxidative and non-oxidative conditions were markedly different indicating differences in the mechanisms and thermal reactivity for the coals. The findings indicate that thermal degradation behaviour of coals is also significantly dependent on the nature of the oxidising environment (Nyakuma and Jauro 2016a), as similarly observed for the composition of the organic materials or maceral components in the literature (Luo and Agraniotis 2017).

\subsection{Kinetic properties}

In this study, the kinetic analysis of the newly discovered coals was examined based on the Coats-Redfern Model (CRM). Hence, the kinetic parameters; activation energy $\left(E_{\mathrm{a}}\right)$ and pre-exponential factor $\left(k_{\mathrm{o}}\right)$ for the pyrolysis and combustion were calculated from the slope and intercepts of the plots in Figs. 10 and 11. The kinetic parameters were calculated for thermal degradation of each coal between $T_{\text {ons }}$ and $T_{\text {off }}$ temperatures; since this stage is considered the rate-determining step during TGA (Nyakuma et al. 2016).

Figures 10 and 11 exhibits the downward sloping Arrhenius kinetic plots, which typically occur from left to right, as observed for thermally degrading materials in the literature (Sonibare et al. 2005). The plots for the combustion process are straight-line plots with higher $R^{2}$ values, whereas the pyrolytic decomposition of the samples showed slightly curved plots, hence the slightly lower coefficients of regression $\left(R^{2}\right)$ values (see Table 5). Based on the plots, the activation energy $\left(E_{\mathrm{a}}\right)$, pre-exponential factor $\left(k_{\mathrm{o}}\right)$, and coefficient of regression $\left(R^{2}\right)$ for the thermal degradation of the coals were computed as shown in Table 5 .

The findings indicate that the $E_{\mathrm{a}}$ values for the combustion process ranged from 74.99 to $89.56 \mathrm{~kJ} / \mathrm{mol}$, whereas the pyrolysis process was characterised by lower $E_{\mathrm{a}}$ values between 23.81 and $36.96 \mathrm{~kJ} / \mathrm{mol}$. In contrast, the $k_{\mathrm{o}}$ values for the combustion process were observed between $1.13 \times 10^{2}$ and $1.72 \times 10^{3} / \mathrm{min}$, whereas the pyrolysis process was characterised by lower $k_{\mathrm{o}}$ values from $6.77 \times 10^{-4}$ to $1.41 \times 10^{-2} / \mathrm{min}$. The kinetic results for the combustion and pyrolysis values were obtained at high $R^{2}$ values ranging from 0.95 to 0.98 as shown in Table 5 . The activation energy $\left(E_{\mathrm{a}}\right)$, pre-exponential factor $\left(k_{\mathrm{o}}\right)$, and coefficient of regression $\left(R^{2}\right)$ were also determined for various ranks of other Nigerian coals in the literature (Sonibare et al. 2005). The findings of Sonibare et al. (2005) indicate the ranges of values of $E_{\mathrm{a}}, k_{\mathrm{o}}$, and $R^{2}$ 


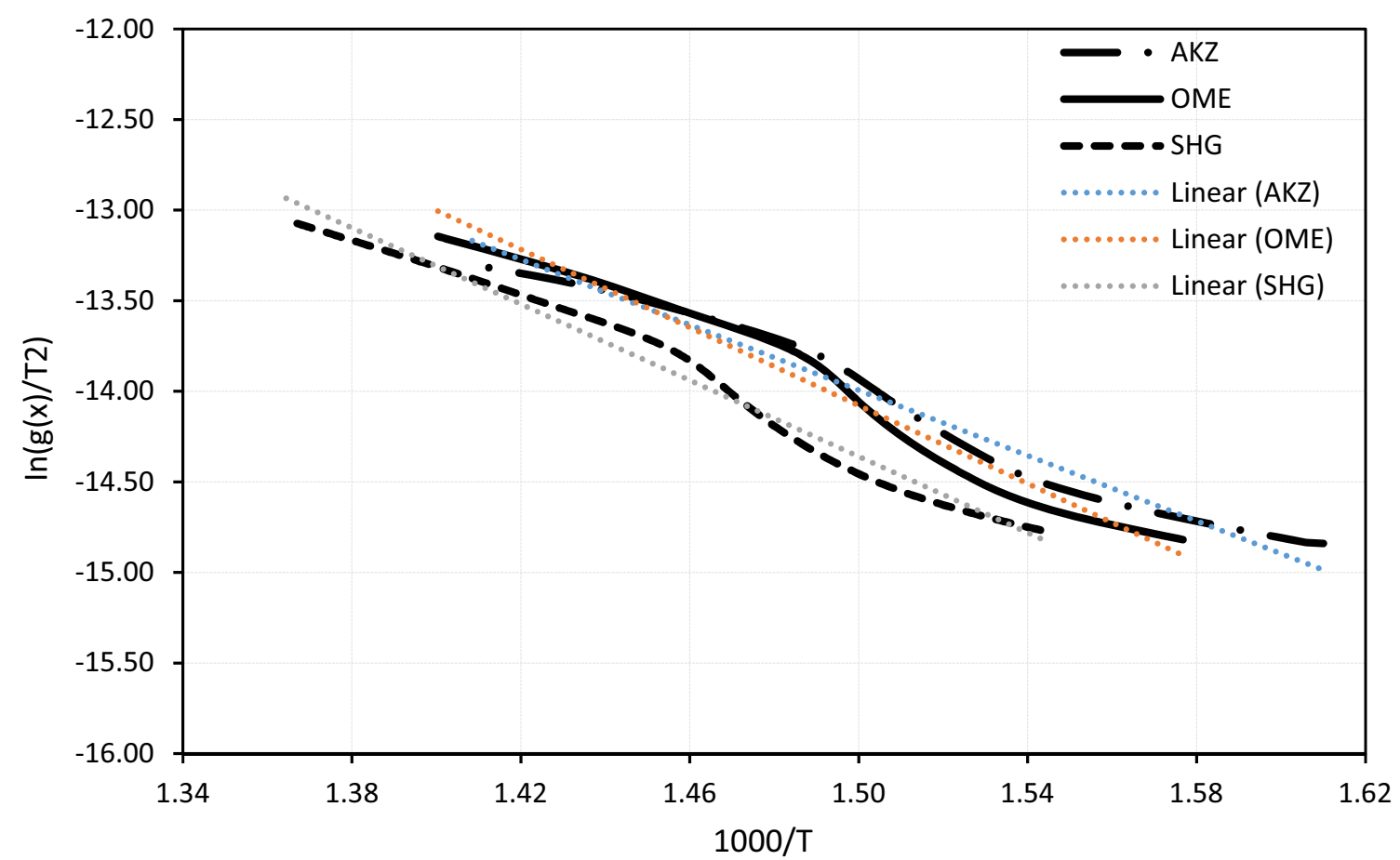

Fig. 10 Kinetic plots for combustion (CMB) of Nigerian coals

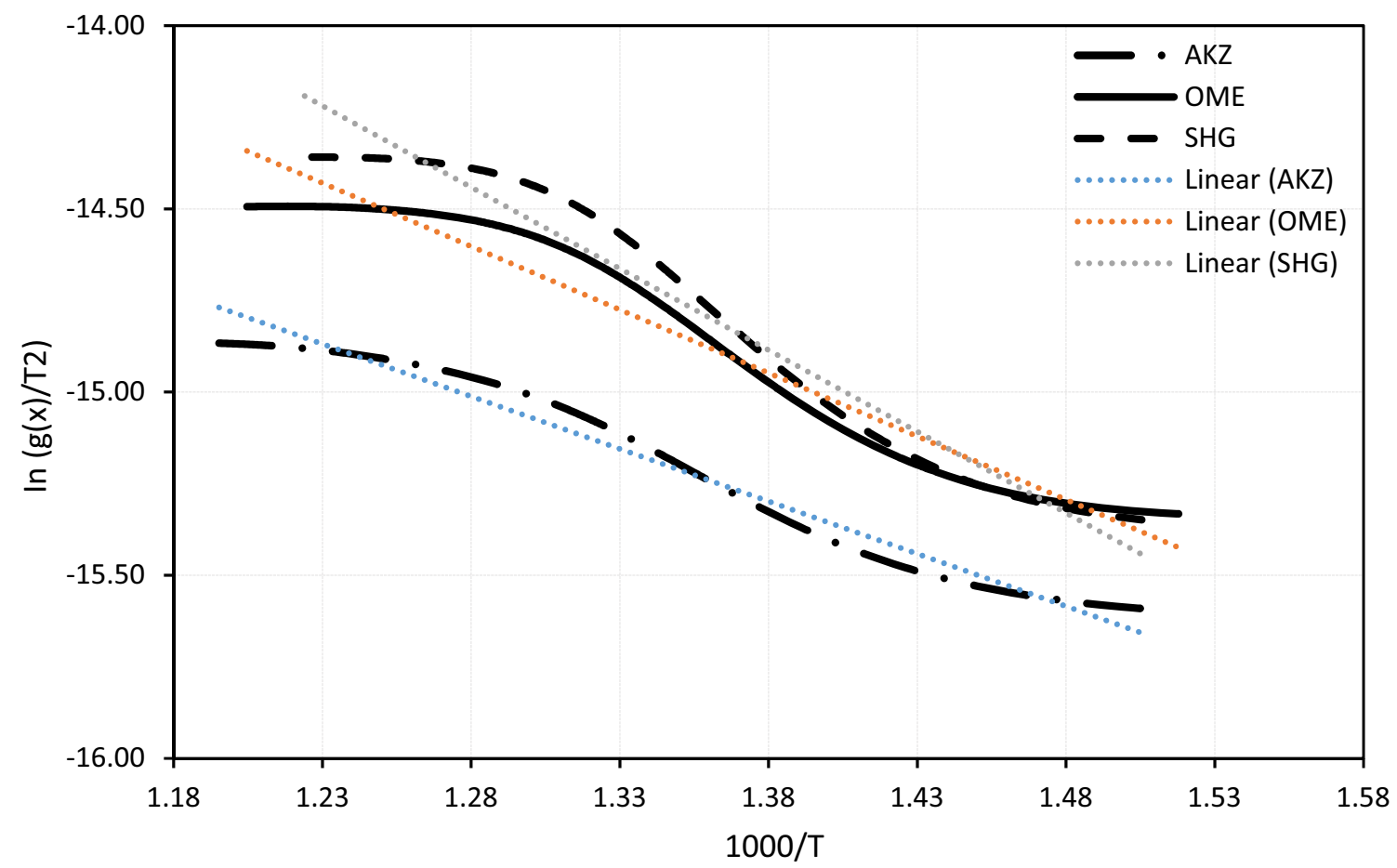

Fig. 11 CRM kinetic plots for pyrolysis (PYR) of Nigerian coals

for the combustion process were; 68.50-90.90 kJ/mol, $4.3 \times 10^{1}-6.7 \times 10^{2} / \mathrm{min}$, and $0.980-0.994$, whereas the values for pyrolysis were; $34.10-57.20 \mathrm{~kJ} / \mathrm{mol}$, $4.6 \times 10^{-3}-3.00 \times 10^{-1} / \mathrm{min}$, and $0.971-0.996$. Hence, the kinetic parameters determined in this study for AKZ,
OME, and SHG are fairly good agreement with values reported in the literature. Furthermore, the kinetic parameters $\left(E_{\mathrm{a}}, k_{\mathrm{o}}\right.$, and $\left.R^{2}\right)$ for the combustion reported in this study are higher than the pyrolysis process, as also reported by Sonibare et al. (2005). This observation could be 
Table 5 Kinetic properties of Nigerian coals under pyrolysis and combustion conditions

\begin{tabular}{|c|c|c|c|c|c|}
\hline Coal sample & Reaction & TPC temperature range $\left({ }^{\circ} \mathrm{C}\right)$ & $E_{\mathrm{a}}(\mathrm{kJ} / \mathrm{mol})$ & $k_{\mathrm{o}}\left(\min ^{-1}\right)$ & $R^{2}$ \\
\hline $\mathrm{AKZ}$ & Combustion & $349.64-436.66$ & 74.99 & $1.13 \times 10^{02}$ & 0.98 \\
\hline OME & & $361.05-440.24$ & 89.56 & $1.72 \times 10^{03}$ & 0.98 \\
\hline SHG & & $374.93-459.39$ & 87.44 & $8.66 \times 10^{02}$ & 0.98 \\
\hline $\mathrm{AKZ}$ & Pyrolysis & $363.35-594.32$ & 23.81 & $6.77 \times 10^{-04}$ & 0.97 \\
\hline OME & & $385.95-556.11$ & 28.74 & $2.63 \times 10^{-03}$ & 0.95 \\
\hline SHG & & $391.13-543.03$ & 36.96 & $1.41 \times 10^{-02}$ & 0.96 \\
\hline
\end{tabular}

ascribed to the exothermic and endothermic nature of the combustion and pyrolysis processes during TGA. Typically, endothermic reactions such as pyrolysis are favoured by higher temperatures as opposed to exothermic reactions such as combustion. Likewise, the rank and fuel properties of coal may also account for thermal reactivity and degradation during TGA (Nyakuma 2016). As stated earlier, AKZ and OME are lower-ranked coals, which explains their lower $E_{\mathrm{a}}$ values (higher thermal reactivity) compared to SHG during the pyrolytic thermal degradation process during TGA. However, the trend observed for the combustion process is slightly different with SHG showing fairly similar $E_{\mathrm{a}}$ to the lower-ranked OME coal, which is explained by the higher VM of SHG (see Table 1) of the former compared to the latter. The findings confirm the rank, classification, and thermal degradation behaviour of the coals, as earlier surmised in the study.

\section{Potential applications and future outlook}

The physicochemical, microstructure, mineralogy, thermal, and kinetic fuel properties of three newly discovered coal samples from Akunza (AKZ), Ome (OME), and Shiga (SHG) from Nigeria have been presented in detail. This section of the paper seeks to highlight the potential applications and future outlook on these coals. Based on the physicochemical fuel properties, AKZ, OME, and SHG coals are highly carbonaceous materials with significant potentials for energy recovery and industrial utilisation. In particular, the AKZ (classified as Lignite A) and OME (Subbituminous B) coals are suited for electric power generation along with the production of cement, fertilisers and chemicals due to their low-rank coal (LRC) status.

Furthermore, the AKZ and OME samples examined in this study have similar fuel properties with other lignites from Obomkpa, Ihioma, and Ogboligbo (Nyakuma 2019) and Subbituminous Nigerian coals such as Owukpa (Nyakuma et al. 2019a) and Garin Maiganga (Nyakuma and Jauro 2016b). Lignite is an essential fuel source in many countries, where it is utilised for the production of electric power $(79 \%)$, synthetic natural gas $(\mathrm{SNG})(13 \%)$, fertilizer (7\%), along with heating homes and oil drilling (Lignite Energy Council 2020). However, the energy or industrial applications of lignite and subbituminous coals are nonexistent in Nigeria, despite accounting for about $12 \%$ and $49 \%$, respectively, of all proven and inferred coal resources (Chukwu et al. 2016).

In contrast, SHG coal (high-volatile C Bituminous or Subbituminous A) is considered a mid-high ranked coal with potential for application in the production of thermal (steam) coal, metallurgical coking coal or the manufacture of iron and steel in the industry (Speight 2012). The global demand for coal is projected to remain high at 5645 MTCE (million tonnes of coal equivalent), particularly due to the demand for thermal (steam) coal and metallurgical coking coal utilised for electricity and steel manufacturing (IEA 2020). According to the World Coal Association, coal accounts for around $70 \%$ of all steel produced globally where it is used as either the primary energy source or energy input for the electric-powered arc kilns. Likewise, the cement industry is heavily reliant on coal for energy supply typically requiring about $200 \mathrm{~kg}$ of coal to produce $1000 \mathrm{~kg}$ of cement. Over the years, the higher-ranked coals have also become integral feedstock for the production of coal-derived fuels (through coal-to-liquid technologies), which account for $7.5 \%-20.0 \%$ of the transport and jet fuels in South Africa and other countries around the globe (World Coal Association 2017).

The thermochemical conversion of coals through liquefaction, pyrolysis, and gasification processes is another promising route for the production of high-value fuels (syngas, hydrogen), chemicals (methanol, dimethyl ether), and high-value hydrocarbons such as benzene, toluene, and xylene (BTX). The high volatile matter $(\mathrm{VM}=37.74 \mathrm{wt} \%)$ of SHG coal indicates its feedstock suitability for thermochemical conversion through gasification. On the other hand, the $\mathrm{AKZ}$ coal is more suited for pyrolysis into coke, coal liquids, and syngas due to its lower volatile matter $(\mathrm{VM}=26.18 \mathrm{wt} \%)$ and higher fixed carbon $(\mathrm{FC}=58.38$ wt $\%$ ) contents compared to OME and SHG coals. In general, any of the three samples could be a potential feedstock 
for pulverised coal combustion (PCC) in future coal-fired power plants. However, the potential utilisation of such coals is contingent on addressing the associated challenges of environmental pollution (air, water) and the risks to human health and safety arising from GHG and toxic pollutant emissions.

Various studies have proposed the adoption and implementation of clean coal technologies (CCT) such as the high-efficiency low emission (HELE) power plants. Other notable innovations proposed include lignite beneficiation, particulate bag houses, subcritical steam boiler technology, carbon injection technology, selective catalytic reduction (SCR), flue gas desulphurisation (FGD) among other retrofit technologies (Reid 2016). The integrated deployment of such technologies reportedly increases coal conversion efficiency and reduces emissions. Such innovative technologies also enhance power plant performance from $\sim$ $28 \%$ for current lignite fleets to $\sim 40 \%$ in hard coal electricity stations and $46 \%$ in integrated coal gasification combined cycle (IGCC) plants along with net $\mathrm{CO}_{2}$ savings, GHG and other $\left(\mathrm{Hg}, \mathrm{SO}_{x}, \mathrm{NO}_{x}\right.$ and $\left.\mathrm{PM}\right)$ emissions control (DOE-NETL 2020).

The metallic elements, minerals, or aluminosilicates such as quartz and kaolinite in the coal samples examined in this study could be potentially extracted and exploited as mineral resources. The extracted minerals and metallic elements have wide-ranging applications in catalysis, silicon wafer manufacture, photovoltaic (PV) cells, hightemperature glass and ceramics manufacturing (Dedzo and Detellier 2016), along with cosmetics, fine chemicals, fuel cells, battery, energy storage and nano-based materials (Leiviskä et al. 2012). Other notable applications include the manufacture of soap, detergent, packaging materials, and water treatment (Das et al. 2020) along with paper, construction and medical diagnostics (Babisk et al. 2020).

\section{Conclusions}

The study comprehensively examined the physicochemical, microstructural, mineralogical, thermal and kinetic fuel properties of the three newly discovered AKZ, OME, and SHG coal samples from Nigeria. The findings showed that the new coal samples contain high combustible elements and energy content but low pollutant elements such as sulphur and nitrogen, which could enhance future energy recovery. Based on the physicochemical, AKZ, OME, and SHG can be classified as lignite, subbituminous and bituminous rank coals, respectively. The microstructure of the coals is characterised by particles with rough texture, surface, and a distinct glassy sheen due to metallic elements, minerals, clays and aluminosilicates. Thermal analysis revealed significant mass loss $\left(M_{\mathrm{L}}\right)$ due to thermal degradation of coal macerals during oxidative and nonoxidative TGA. Kinetic analysis showed that the coal samples are highly reactive with low $E_{\mathrm{a}}$ and $k_{\mathrm{o}}$ values under both oxidative and non-oxidative conditions. Hence, the coal samples are suitable for coal-fired electricity generation and potential energy recovery through pyrolysis, gasification, and combustion. In addition, the coal samples could be employed as potential feedstocks for the large-scale production of cement, iron, steel, coke, chemicals, and liquid transportation fuels. However, further studies are recommended to investigate the exergy, evolved gas analysis, pollutant profiles, and life cycle analysis for future power plants or industrial applications.

Acknowledgements The authors gratefully acknowledge Universiti Teknologi Malaysia (UTM) Malaysia, Federal University Lafia, and University Industrial Research Laboratory (UiRL) at UTM for the material and technical support.

Author contributions BBN: original manuscript draft; AJ: writing review; SAA: editing and fact-checking; HMF: revisions, editing, and proofing; MBN: conceptualisation and coal procurement; MAHM: experimental design; OO: methodology and data analysis.

Funding This research did not receive any form of funding or financial support from any organisation.

Availability of data and materials All the data in the manuscript is presented in the form of tables and figures.

\section{Compliance with ethical standards}

Conflict of interest The authors declare no conflict of interest whatsoever.

Open Access This article is licensed under a Creative Commons Attribution 4.0 International License, which permits use, sharing, adaptation, distribution and reproduction in any medium or format, as long as you give appropriate credit to the original author(s) and the source, provide a link to the Creative Commons licence, and indicate if changes were made. The images or other third party material in this article are included in the article's Creative Commons licence, unless indicated otherwise in a credit line to the material. If material is not included in the article's Creative Commons licence and your intended use is not permitted by statutory regulation or exceeds the permitted use, you will need to obtain permission directly from the copyright holder. To view a copy of this licence, visit http://creativecommons. org/licenses/by/4.0/.

\section{References}

Abubakar M (2014) Petroleum potentials of the Nigerian Benue Trough and Anambra Basin: a regional synthesis. Nat Resour 5(1):25-58. https://doi.org/10.4236/nr.2014.51005

Agroskin A, El-Goncharo G, Gryaznov N (1972) Thermal properties of coals in plastic state. Coke Chem 1:3-5

Akande SO, Ogunmoyero I, Petersen H, Nytoft H (2007) Source rock evaluation of coals from the Lower Maastrichtian Mamu Formation, SE Nigeria. J Pet Geol 30:303-324 
Akinyemi SA, Adebayo OF, Nyakuma BB, Adegoke AK, Aturamu OA, OlaOlorun OA, Adetunji A, Hower JC, Hood MM, Jauro A (2020a) Petrology, physicochemical and thermal analyses of selected cretaceous coals from the Benue Trough Basin in Nigeria. Int J Coal Sci Technol 7:26-42. https://doi.org/10.1007/ s40789-020-00303-6

Akinyemi SA, Gitari WM, Thobakgale R, Petrik LF, Nyakuma BB, Hower JC, Ward CR, Oliveira MLS, Silva LFO (2020b) Geochemical fractionation of hazardous elements in fresh and drilled weathered South African coal fly ashes. Environ Geochem Health. https://doi.org/10.1007/s10653-019-00511-3

ASTM D388-12 (2012) Standard classification of coals by rank. ASTM International, West Conshohocken

ASTM E2550-17 (2017) Standard test method for thermal stability by thermogravimetry vol book of standards volume: 14.05. ASTM International, West Conshohocken

Ayinla HA, Abdullah WH, Makeen YM, Abubakar M, Jauro A, Yandoka BMS, Abidin NSZ (2017a) Petrographic and geochemical characterization of the Upper Cretaceous coal and mudstones of Gombe Formation, Gongola sub-basin, northern Benue trough Nigeria: implication for organic matter preservation, paleodepositional environment and tectonic settings. Int $\mathrm{J}$ Coal Geol 180:67-82

Ayinla HA, Abdullah WH, Makeen YM, Abubakar M, Jauro A, Yandoka BMS, Mustapha KA, Abidin NSZ (2017b) Source rock characteristics, depositional setting and hydrocarbon generation potential of Cretaceous coals and organic rich mudstones from Gombe Formation, Gongola sub-basin, Northern Benue Trough, NE Nigeria. Int Jo Coal Geol 173:212-226

Babisk MP, Amaral LF, da Silva Ribeiro L, Vieira CMF, do Prado US, Gadioli MCB, Oliveira MS, da Luz FS, Monteiro SN, da Costa Garcia Filho F (2020) Evaluation and application of sintered red mud and its incorporated clay ceramics as materials for building construction. J Mater Res Technol 9:2186-2195

Baruya P (2017) International finance for coal-fired power plants. IEA Clean Coal Centre, London

Benkhelil J (1989) The origin and evolution of the Cretaceous Benue Trough (Nigeria). J Afr Earth Sci (Middle East) 8:251-282

BP (2018) BP statistical review of world energy 2017. British Petroleum, London

Cebeci Y, Ulusoy U, Şimşek S (2002) Investigation of the effect of agglomeration time, $\mathrm{pH}$ and various salts on the cleaning of Zonguldak bituminous coal by oil agglomeration. Fuel 81:1131-1137

Chukwu M, Folayan C, Pam G, Obada D (2016) Characterization of some Nigerian coals for power generation. J Combust 2016:1-11. https://doi.org/10.1155/2016/9728278

Coats AW, Redfern JP (1964) Kinetic parameters from thermogravimetric data. Nature 201:68-69. https://doi.org/10.1038/ $201068 \mathrm{a} 0$

Dai S, Finkelman RB (2018) Coal as a promising source of critical elements: progress and future prospects. Int $\mathrm{J}$ Coal Geol 186:155-164

Das I, Das S, Dixit R, Ghangrekar M (2020) Goethite supplemented natural clay ceramic as an alternative proton exchange membrane and its application in microbial fuel cell. Ionics 26:3061-3072. https://doi.org/10.1007/s11581-020-03472-1

Dedzo GK, Detellier C (2016) Functional nanohybrid materials derived from kaolinite. Appl Clay Sci 130:33-39

DOE-NETL (2020) Integrated gasification combined cycles (IGCC) efficiency and performance. United States Department of Energy. https://bit.ly/33BeZcd. Accessed 8th Aug 2020

Donahue CJ, Rais EA (2009) Proximate analysis of coal. J Chem Educ 86:222. https://doi.org/10.1021/ed086p222
Dorf RC (2017) Systems, controls, embedded systems, energy, and machines, the electrical engineering handbook, vol 2. CRC Press, Oxford

Gluskoter H (1975) Mineral matter and trace elements in coal. In: Babu S (ed) Trace elements in fuel. Advances in chemistry series. American Chemical Society, Washington

Gräbner M (2014) Industrial coal gasification technologies covering baseline and high-ash coal. Wiley, Hoboken

Hancox P (2016) The coalfields of South-Central Africa: a current perspective. Episodes 39:407-428

Hanrot F, Ablitzer D, Houzelot J, Dirand M (1994) Experimental measurement of the true specific heat capacity of coal and semicoke during carbonization. Fuel 73:305-309

IEA (2018) Market report series: coal 2018. International Energy Agency, Paris

IEA (2020) Global coal demand by forecast for 2000-2024. International Energy Agency. https://bit.ly/2Q4Wbdn. Accessed 08 Aug 2020

IEA-CCC (2020) Cambodia: two coal power plants built in preah sihanouk. IEA Clean Coal Centre. https://bit.ly/2PYsJpT. Accessed 8th Mar 2020

ISO E (2014) 11358-1: 2014 plastics. thermogravimetry (TG) of polymers. Part 1: general principles. European Standard

Jauro A, Obaje N, Agho M, Abubakar M, Tukur A (2007) Organic geochemistry of Cretaceous Lamza and Chikila coals, upper Benue trough, Nigeria. Fuel 86:520-532

Jauro A, Horsfield B, Wilkes H, Abubakar MB (2014) Hydrocarbon generating potentials of benue trough coals. In: Bhowon MG, Jhaumeer-Laulloo S, Wah HL, Ramasami P (eds) Chemistry: the key to our sustainable future. Springer, Berlin, pp 75-91

Karayigit AI, Gayer RA, Ortac FE, Goldsmith S (2001) Trace elements in the Lower Pliocene fossiliferous kangal lignites, Sivas, Turkey. Int J Coal Geol 47:73-89

Košina M, Heppner P (1984) Macerals in bituminous coals and the coking process: Part 1: Effect of basic coal properties on the process of thermal degradation. Fuel 63:838-846

Landais P, Muller J-F, Michels R, Oudin J-L, Zaugg P (1989) Comparative behaviour of coal and maceral concentrates during artificial coalification. Fuel 68:1616-1619

Leiviskä T, Gehör S, Eijärvi E, Sarpola A, Tanskanen J (2012) Characteristics and potential applications of coarse clay fractions from Puolanka, Finland. Open Eng 2:239. https://doi.org/10. 2478/s13531-011-0067-9

Lignite Energy Council (2020) Percentages of how lignite energy is used. LEC. https://bit.ly/30FNo7Y. Accessed 08 Aug 2020

Liu D, Peng Y (2015) Understanding different roles of lignosulfonate in dispersing clay minerals in coal flotation using deionised water and saline water. Fuel 142:235-242

Luo Z, Agraniotis M (2017) Low-rank coals for power generation, fuel and chemical production. Woodhead Publishing, Sawston

Miller BG (2016) Clean coal engineering technology. technology and engineering, vol 2. Butterworth-Heinemann (Elsevier Science), Oxford

Musa D (2010) The economics of electric power supply in Nigeria. Gamji. https://bit.ly/2YeoLgU. Accessed 12 Apr 2020

Nyakuma B (2016) Physicochemical characterization and thermal analysis of newly discovered Nigerian coals. Bulg Chem Commun 48:746-752

Nyakuma BB (2019) Physicochemical geomineralogical, and evolved gas analyses of newly discovered Nigerian Lignite Coals. Coke Chem 62:394-401

Nyakuma BB, Jauro A (2016a) Chemical and pyrolytic thermogravimetric characterization of Nigerian bituminous coals. Geosci Eng 62:1-5 
Nyakuma BB, Jauro A (2016b) Physicochemical characterization and thermal decomposition of Garin Maiganga coal. GeoSci Eng 62:6-11

Nyakuma B, Jauro A, Oladokun O, Uthman H, Abdullah T (2016) Combustion kinetics of Shankodi-Jangwa coal. J Phys Sci 27:1-12

Nyakuma B, Oladokun O, Abdullah T, Ojoko E, Abdullahi M, ElNafaty A, Ahmed A (2018) Carbonization and coke characteristics of Ogboligbo coal. Coke Chem 61:424-432

Nyakuma B, Oladokun O, Akinyemi S, Ojoko E, Jacob G, Abdullah T, Alkali H, Al-Shatri A (2019a) Comprehensive evaluation of the combustion kinetic characteristics of Owukpa coal. Coke Chem 62:371-378

Nyakuma BB, Jauro A, Oladokun O, Akinyemi SA, Nasirudeen MB, Bello AA, Alkali H, Abdullah TAT (2019b) Fuel characteristics of duduguru coal from Nasarawa State in Nigeria. Pet Coal 61:682-689

Ocheri C (2017) Revitalization of coal development in Nigeria for industrial advancement. SF J Metall Sci 1:1-9

Odior AO, Omadudu CM (2013) Some factors responsible for erratic power supply in Benin City area of Edo state. Int J Syst Assur Eng Manag 4:48-56. https://doi.org/10.1007/s13198-012-0126-5

Odior A, Oyawale F (2012) A review of some of the operations of power holding company of Nigeria. Int J Syst Assur Eng Manag 3:160-168

Offodile ME (1976) The geology of the middle Benue Nigeria vol 4. Stratigraphy, palaeontology, and hydrography. University of Uppsala, Paleontological Institute, Uppsala

Offodile M (1980) A mineral survey of the Cretaceous of the Benue Valley, Nigeria. Cretac Res 1:101-124

Ogala JE (2018) Geochemistry of coal and coal bearing strata from the Upper Cretaceous Mamu Formation, Southeastern Nigeria: implications for Paleoredox history. FUW Trends Sci Technol J 3:787-796

Ogala J, Siavalas G, Christanis K (2012) Coal petrography, mineralogy and geochemistry of lignite samples from the OgwashiAsaba Formation, Nigeria. J Afr Earth Sci 66:35-45

Ogungbesan G, Akaegbobi I (2011) Petrography and geochemistry of turonian eze-aku sandstone Ridges, lower Benue trough, Nigeria implication for provenance and tectonic settings. Ife J Sci 13:263-277

Ohimain EI (2014) Can Nigeria generate $30 \%$ of her electricity from coal? Int J Energy Power Eng 3:28-37

Olade M (1975) Evolution of Nigeria's Benue Trough (Aulacogen): a tectonic model. Geol Mag 112:575-583

Oseni MO (2011) An analysis of the power sector performance in Nigeria. Renew Sustain Energy Rev 15:4765-4774

Oyedepo SO (2012a) Energy and sustainable development in Nigeria: the way forward. Energy Sustain Soc 2:15

Oyedepo SO (2012b) On energy for sustainable development in Nigeria. Renew Sustain Energy Rev 16:2583-2598

Oyedepo SO (2014) Towards achieving energy for sustainable development in Nigeria. Renew Sustain Energy Rev 34:255-272

Özer M, Basha OM, Morsi B (2017) Coal-agglomeration processes: a review. Int J Coal Prep Util 37:131-167

Reddy PJ (2013) Clean coal technologies for power generation. CRC Press, Boca Raton

Reid I (2016) How to improve the performance of lignite power plants? IEA-CCC. https://bit.ly/2Dxn6fd. Accessed 8 Aug 2020

Sambo A (2009) Prospect of coal for power generation in Nigeria. In: A paper presented at the international workshop for the promotion of coal for power generation. pp 27-28
Sellaro R, Sarver E, Baxter D (2015) A standard characterization methodology for respirable coal mine dust using SEM-EDX. Resources 4:939-957

Sengupta P, Saikia PC, Borthakur PC (2008) SEM-EDX characterization of an iron-rich kaolinite clay. J Sci Res 67:812-818

Sonibare O, Ehinola O, Egashira R, KeanGiap L (2005) An investigation into the thermal decomposition of Nigerian coal. J Appl Sci 5:104-107

Sonibare O, Jacob D, Foley S (2013) Quantitative estimation of major and trace elements in coals of the Benue Trough, Nigeria. Energy Sources Part A Recov Util Environ Eff 35:753-761

Spears D (2000) Role of clay minerals in UK coal combustion. Appl Clay Sci 16:87-95

Speight JG (2012) The chemistry and technology of coal. Chemical Industries, 3rd edn. CRC Press, TBoca Raton

Strezov V, Morrison A, Nelson P (2007) Thermal study of the coking behaviour of thermoplastic coals. Macquarie University, Sydney

Sun Q-L, Li W, Chen H-K, Li B-Q (2003) TG-MS study on pyrolysis behavior of Shenmu coal macerals. J China Univ Min Technol 32:664-669

Tang X, Jin Y, McLellan BC, Wang J, Li S (2018) China's coal consumption declining-Impermanent or permanent? Resour Conserv Recycl 129:307-313

Uzoegbu U, Uchebo U, Okafor I (2013) Lithostratigraphy of the Maastrictian Nsukka Formation in the Anambra Basin, SE Nigeria. J Environ Sci Toxicol Food Technol 5:96-102

Wierzbowski M, Filipiak I, Lyzwa W (2017) Polish energy policy 2050-An instrument to develop a diversified and sustainable electricity generation mix in coal-based energy system. Renew Sustain Energy Rev 74:51-70

Wong S, Mah AXY, Nordin AH, Nyakuma BB, Ngadi N, Mat R, Amin NAS, Ho WS, Lee TH (2020) Emerging trends in municipal solid waste incineration ashes research: a bibliometric analysis from 1994 to 2018. Environ Sci Pollut Res 27:7757-7784. https://doi.org/10.1007/s11356-020-07933-y

World Coal Association (2017) Basic coal facts. World Coal Association (WCA). https://bit.ly/3iOrPbe. Accessed 8 Aug 2020

Wuyep EO, Obaje NG (2012) Petrographic evaluation of the ranks and technological applications of some coal deposits in the Anambra Basin and Middle Benue Trough of Nigeria. J Earth Sci Eng 2:220-234

Xie W, Stanger R, Lucas J, Wall T, Mahoney M (2013) Coal macerals separation by reflux classification and thermo-swelling analysis based on the computer aided thermal analysis. Fuel 103:1023-1031

Yandoka BMS, Abdullah WH, Abubakar M, Hakimi MH, Jauro A, Adegoke AK (2016) Organic geochemical characterisation of shallow marine Cretaceous formations from Yola Sub-basin, Northern Benue Trough, NE Nigeria. J Afr Earth Sci 117:235-251

Zhao S, Alexandroff A (2019) Current and future struggles to eliminate coal. Energy Policy 129:511-520

Zhao Y, Hu H, Jin L, He X, Wu B (2011) Pyrolysis behavior of vitrinite and inertinite from Chinese Pingshuo coal by TG-MS and in a fixed bed reactor. Fuel Process Technol 92:780-786

Zou C, Ma C, Zhao J, Shi R, Li X (2017) Characterization and nonisothermal kinetics of Shenmu bituminous coal devolatilization by TG-MS. J Anal Appl Pyrolysis 127:309-320. https://doi.org/ 10.1016/j.jaap.2017.07.020 